\title{
EDUCACIÓN, JUECES Y CONSTITUCIÓN, 1978-2020 (II): LOS DERECHOS MENTALES Y EDUCATIVOS DE LOS MENORES
}

\author{
Education, judiciary and Constitution, 1978-2020 (II). \\ The mental and educational rights of minors
}

\section{Antonio Viñao Frago ${ }^{\alpha}$}

Fecha de recepción: 10/12/2020 • Fecha de aceptación: 08/03/2021

Resumen. Este ensayo versa sobre la vigencia en España de los derechos mentales, (in)formativos y educativos reconocidos en la Convención sobre los Derechos del Niño de 1989, en especial en relación con los derechos de los padres a que sus hijos reciban una formación religiosa y moral acorde con sus convicciones (art. 27.3 de la Constitución de 1978). Tras una referencia histórica a los mencionados derechos de los menores, se analiza dicha Convención y su desarrollo legal en España, así como la naturaleza, titularidad y límites del mencionado derecho de los padres, la libertad de pensamiento, conciencia y religión del menor y el tratamiento judicial de unos y otros derechos en caso de divergencia o conflicto.

Palabras clave: Constitución de 1978; derechos del menor; derechos de los padres; libertad de creencias; libertad de conciencia; Convención de los Derechos del Niño (1989).

Abstract. This essay concerns the respect in Spain of the mental, (in)formative, and educational rights recognized in the 1989 Convention on the Rights of the Child, especially in relation to the rights of parents to have their children receive religious and moral training in accordance with their convictions (art. 27.3 of 1978 Constitution). After a historical reference to the aforementioned rights of minors, the article offers an analysis of the Convention and its legal development in Spain; the nature, propietorship and limits of the rights alluded to of the parents; the child's freedom of thought, conscience

\footnotetext{
${ }^{\alpha}$ Facultad de Educación. Universidad de Murcia. Campus universitario de Espinardo. 30100 Murcia.avinao@um.es
}

Cómo citar este artículo: Viñao Frago, Antonio. «Educación, jueces y constitución, 1978-2020 (II): los derechos mentales y educativos de los menores». Historia y Memoria de la Educación 14 
and religion; and the judicial treatment of both rights in cases of divergence or conflict are analysed.

Keywords: Constitution of 1978; minors' rights; parents' rights; freedom of belief; freedom of conscience; Convention of the Rights of the Child (1989).

\section{INTRODUCCIÓN}

Este trabajo constituye la segunda parte del publicado en 2019 en el número 12 de esta revista sobre el tema de la educación diferenciada o separada por sexos. ${ }^{1}$ Conforme allí se adelantaba, esta segunda parte gira en torno a la vigencia en España de la Convención sobre los Derechos del Niño de 20 de noviembre de 1989 o, más bien, sobre los derechos mentales, (in)formativos y educativos de los menores reconocidos en dicha Convención. ${ }^{2}$ Es conocida la polémica suscitada en todo el país en el curso 2019-2020 por la defensa que desde Vox se hizo, y hace, del «pin parental»-al que denominaré «veto parental»-.3 También la admisión

\footnotetext{
1 Antonio Viñao Frago, «Educación, jueces y constitución, 1978-2018 (I). La educación separada por sexos». Historia y Memoria de la Educación 11 (2020): 435-473.

2 Una vez leídos los informes previos sobre este ensayo, además de agradecer a los evaluadores sus recomendaciones y comentarios, considero necesario realizar dos observaciones en relación con el uso y significado de la expresión «derechos mentales, (in)formativos y educativos de los menores». Aunque el núcleo central del trabajo gire en torno al derecho a la libertad de pensamiento, conciencia y religión -libertad de creencias- del menor, opto por dicha expresión en vez de la de «derechos y libertades civiles», utilizada en los informes del Comité del Niño de las Naciones Unidas, por incluir esta última otros derechos aquí no tratados -el derecho al nombre y la nacionalidad o el de protección de la vida privada- o solo parcialmente considerados -derechos a la libertades de expresión y de asociación y reunión, y a una información pertinente-, así como para poner el acento en la índole mental, (in)formativa y educativa de un derecho dirigido a formar una mente libre y plural en una sociedad en la que la libertad y el pluralismo constituyan, junto con la igualdad, sus principios o valores básicos. Asimismo, utilizo el término «menor» por ser éste el habitual en el ámbito legislativo español, tras haber sustituido al de "niño». En todo caso, dicho término ha de considerarse equivalente al de «NNA», sigla de «niños, niñas, adolescentes», que también suele utilizarse. No está de más indicar que el término "padres» engloba a padres y madres, y que el de "progenitores», en ocasiones utilizado por algunos autores, no incluye a los padres y madres no biológicos.
}

3 Como ha señalado Alex Grijelmo («Los tres problemas del pin parental», El País, 1 de marzo de 2020, suplemento «Ideas», 12), el término pin se presta a confusión. En el lenguaje usual llamamos pin a una insignia que se cuelga en la solapa o prenda de vestir. No es este el significado con que se utiliza en la expresión "pin parental». Su origen se halla en las siglas PIN (personal identification number), password o clave instalada en algunas plataformas de televisión con el fin de impedir que los menores accedan a determinados canales. Dado que, en este caso, no hay clave alguna que impida, a voluntad de los padres o tutores, la enseñanza de determinadas materias en función de sus convicciones religiosas o morales, Grijelmo opta por llamar a las cosas por su nombre dejándose de eufemismos: no estamos, dice, ante un PIN, sino ante un veto «contra [la enseñanza] de una parte 
legal del mismo por el gobierno de la Comunidad Autónoma de Murcia -formado por el Partido Popular junto con Ciudadanos con el apoyo de Vox-, que dio origen a sendos recursos contenciosos presentados por el Sindicato de Trabajadores de la Enseñanza de la Región de Murcia y el Ministerio de Educación, ambos archivados tras la suspensión del curso escolar en su modalidad presencial por la Covid-19. Ambos hechos me han llevado a replantear buena parte de lo entonces pensado para, a partir de dicha polémica y recursos, tratar, desde una perspectiva más amplia, la evolución del tratamiento doctrinal, legal y judicial de los mencionados derechos frente sobre todo a los de sus padres y, ya de paso, a los poderes públicos. ${ }^{4}$ Por lo demás, en este ensayo doy por leído, aunque en algún caso haya que reiterarlo, lo que en el anterior se decía en relación con: a) la índole no estrictamente jurídica del análisis efectuado; b) las diversas y en ocasiones opuestas interpretaciones doctrinales -es decir, a cargo de los juristas que estudian el tema- y judiciales de los artículos de la Constitución relativos directa o indirectamente a la educación; c) la existencia y el alcance del ideario educativo constitucional; y c) el predominio -más en el ámbito judicial que en el doctrinal- de las interpretaciones que allí denominé católico-conservadoras, sin que el adjetivo católico implique necesariamente la adscripción de tales intérpretes a esta confesión religiosa.

La tesis central de esta segunda parte recupera algunos de los planteamientos de la primera. Por ejemplo, aquellos relacionados con la naturaleza «viva» de la Constitución -es decir, la susceptibilidad de ser interpretada de diferentes modos en función de los cambios sociales y culturales de la sociedad española y, sobre todo, de la mentalidad y cosmovisión de quienes tienen asignada profesionalmente la tarea de interpretarla y aplicarla- y la «ceguera» de una buena parte de dichos profesionales, en este caso, ante la Convención de 1989. En la primera parte aludí a su no consideración por el Tribunal Constitucional (TC) en la sentencia de 10 de abril de 2018 que desestimó el recurso de constitucionalidad interpuesto

\footnotetext{
del conocimiento humano». Pese a la preferencia de Grijelmo por la expresión «veto paterno» frente a «parental», opto por esta última.

4 La elaboración de este texto se ha beneficiado de la preparación de la charla y del posterior debate que, con el título de «El derecho de los padres sobre la educación de sus hijos y los derechos del menor». pronuncié en las localidades de Murcia, Alhama de Murcia, Archena, Lorca y Yecla en el marco de las VI Jornadas "Una educación para el siglo XXI. Miradas desde las ciencias y las artes», celebradas en la región de Murcia entre enero y marzo de 2020.
} 
contra la Ley Orgánica para la Mejora de la Calidad Educativa (LOMCE) de 10 de diciembre de 2013. La influencia, no ya presencia explícita, de dicha Convención en nuestra legislación educativa es asimismo escasa y su trascendencia práctica mínima. Y, en cuanto al nivel doctrinal, pondré solo dos ejemplos de dicha ceguera. No generalizables desde luego, pero suficientes para advertir que solo tendemos a ver aquello que encaja en nuestra cosmovisión -ideología, concepción del mundo y de la vida-, y que la posición o lugar desde el que se mira condiciona no solo lo que se ve y lo que queda fuera de la visión, sino también cómo se ve tanto aquello que se ve como lo que queda, como diría un fotógrafo, fuera de campo.

El primero es el capítulo "Artículo 27: Enseñanza», a cargo de un catedrático y un profesor titular de Derecho Constitucional, publicado en 1996 -la Convención sería firmada por España el 26 de enero de 1990 y ratificada el 30 de noviembre del mismo año- en un libro colectivo dirigido por Óscar Alzaga Villamil, catedrático asimismo de Derecho Constitucional y miembro-protagonista de la Unión de Centro Democrático en los debates constitucionales sobre los temas de enseñanza. Ambos autores, al relacionar, entre las "fuentes de los derechos educativos", los «textos internacionales» aplicables en este tema, en función de los dispuesto en el artículo 10.2 de la Constitución, incluyen, como vigente, la Declaración de los Derechos del Niño de 1959, e ignoran la Convención de 1989 pese a haber sido ratificada seis años antes. ${ }^{5}$

¿Un error? Es lo más probable. Todos hemos cometido alguna vez este tipo de errores. No creo que lo sea, sin embargo, el que en un libro sobre los derechos y libertades educativas publicado en 2010, extenso y en general bien documentado, su autor, al relacionar los textos internacionales aplicables al caso, ratificados por España y que «suelen citarse», mencione hasta ocho de ellos sin que en la relación figure la Convención de 1989 porque, en efecto, no suele incluirse entre las declaraciones internacionales relacionadas con la educación. ${ }^{6}$

\footnotetext{
5 Alfonso Fernández-Miranda Campoamor y Ángel J. Sánchez Navarro, «Artículo 27: Enseñanza», en Óscar Alzaga Villamil (dir.), Comentarios a la Constitución española de 1978 (Madrid: Cortes Generales / Editoriales de Derecho Reunidas, 1996), t. III, 165.

6 Juan Andrés Muñoz Arnau, Derechos y libertades en la política y legislación educativas españolas (Pamplona: EUNSA, 2010), 52.
} 
¿Qué tiene dicha Convención, qué se dice en ella que no se diga en la de 1959, para qué se mire hacia otro lado y se considere que no guarda relación alguna con los derechos y libertades educativas? La tesis que mantengo, con independencia de que sea o no esa la razón de tanta ceguera, es que su contenido, los derechos y libertades que reconoce a los menores de 18 años, deberían haber obligado a los comentaristas, expertos y jueces que la interpretan y aplican -en el supuesto de que reconocieran su vigencia y relación con la educación- a replantearse la interpretación de la Constitución hasta ahora dominante en materia de enseñanza. Una interpretación cuyos arcos de bóveda son, por orden de primacía, el derecho de los padres a que sus hijos reciban la formación religiosa y moral que esté de acuerdo con sus convicciones (art. 27.3) y la libertad de enseñanza entendida exclusivamente como libertad de creación de centros docentes (arts. 27.1 y 27.6) de donde derivan, con carácter de necesidad, el derecho de los titulares de centros privados a establecer un ideario de centro y la libertad de elección de centro docente por los padres. E incluso, en algún caso, el derecho a la concesión de un concierto si se solicita. Una interpretación que entiende que el constitucional «valor superior» del «pluralismo político» (art. 1.1) queda satisfecho, en lo que a la educación se refiere, con la implantación de un pluralismo intercentros que facilite la elección por los padres de un tipo u otro de educación. De ahí que -un ejemplo más de «ceguera»- haya quien, desde dicha interpretación del texto constitucional, no considere siquiera necesario mencionar la Convención de 1989 al analizar, con detalle y claridad, el «contenido y extensión» del citado art. 27.3 de la Constitución y, por tanto, se quite de encima el esfuerzo mental de argumentar sobre la posible conciliación o conflicto entre el derecho garantizado a los padres en dicho artículo y los reconocidos a los menores en la referida Convención. ${ }^{7}$ El silencio es la mejor respuesta.

\section{LA EMERGENCIA DE UN NUEVO CONCEPTO Y PARADIGMA DE LA INFANCIA COMO SUJETO DE DERECHOS (SIGLOS XIX-XX)}

Suele afirmarse que, a diferencia de lo establecido en las Declaraciones de los Derechos del Niño de 26 de diciembre de 1924, aprobada por

\footnotetext{
7 Joaquín Mantecón Sancho, «Nota en torno al contenido y extensión del artículo 27.3 de la Constitución» en Estudios de Derecho español y europeo, coords. Margarita Serna Vallejo y Consuelo Arranz de Andrés (Santander: Publican, 2009), 541-552.
} 
la Sociedad de Naciones, y de 20 de noviembre de 1959, proclamada por la Naciones Unidas, ha sido en la Convención de 20 de noviembre de 1989, acordada asimismo por las Naciones Unidas, cuando se han reconocido de modo claro, completo y preciso los derechos civiles y, con ellos, los mentales, (in)formativos y educativos de la población menor de 18 años.

En efecto, en la primera de dichas declaraciones, la de 1924 -un texto de solo cinco artículos o principios, mera «declaración de buenas intenciones» que «no emplea el término derechos humanos» y que «considera al niño como un objeto al que hay que cuidar»- ${ }^{8}$ no se iba más allá de recomendar que «El niño debe ser educado en el sentimiento de que sus mejores cualidades deben ser puestas al servicio de sus hermanos» (principio $5^{\circ}$ ). En la de 1959 se establecía en su principio VII, además del derecho al disfrute de «juegos y recreaciones», el derecho a una educación "gratuita y obligatoria por lo menos en las etapas elementales», así como a «una educación que favorezca su cultura general y le permita, en condiciones de igualdad de oportunidades, desarrollar sus aptitudes y su juicio individual, su sentido de responsabilidad moral y social, y llegar a ser un miembro útil de la sociedad». La «responsabilidad de su educación y orientación»se atribuía «en primer término a los padres», si bien «el principio rector», en el ejercicio de dicha responsabilidad, debía ser «el interés superior del niño», una afirmación, esta última, de enorme trascendencia posterior. En síntesis, ambas declaraciones estaban más dirigidas hacia la protección física y social, sobre todo en circunstancias que supusieran amenaza, peligro o discriminación para la infancia, que a la formulación específica de una serie de derechos y libertades que desarrollaran, tras 1948 y en relación con los menores, la Declaración Universal de Derechos Humanos (DUDH) de dicho año. Ese desarrollo se llevaría a cabo, de modo general, ${ }^{9}$ en la Convención de 1989, sin que ello signifique que no existan antecedentes y propuestas anteriores que iluminen el camino recorrido. La referencia, en el caso español, a algunos antecedentes

\footnotetext{
8 María Isabel Álvarez Vélez, «La política de protección de menores en el ámbito internacional». En Jesús Rodríguez Torrente (ed.). El menor y la familia: conflictos e implicaciones (Madrid: Universidad Pontificia Comillas, 1998), 175.

9 Es obvio que, en relación con el derecho a la educación, un primer desarrollo del mismo tendría lugar con la aprobación del Pacto Internacional de Derechos Económicos, Sociales y Culturales de 16 de diciembre de 1966 (art. 13).
} 
históricos puede ayudarnos a entender lo que hay en juego tras dicha Convención y su actual vigencia constitucional. ${ }^{10}$

Una de las defensas más esclarecedoras y taxativas de lo que él llamó los «derechos mentales de la infancia»-es decir, de la libertad religiosa y de creencias infantil- es la efectuada por Blanco White en tres textos escritos entre 1836 y 1840 , durante los últimos años de su vida en Liverpool. ${ }^{11}$ En el primero de ellos, frente a quienes mantenían que «el primer derecho de los niños es que se les enseñe la divina Verdad», Blanco White argumenta y pide a «los amigos de la educación» que tomen «en consideración este punto importante, verdaderamente fundamental: si los niños tienen o no derechos mentales naturales que todos los padres deben respetar». ${ }^{12}$ En el segundo, comentando un libro escolar titulado «El libro del niño sobre el alma», sostiene que «el autor, por supuesto, pertenece a esa multitud desgraciadamente inmensa que cree en el derecho y deber de todos los padres de apoderarse de las mentes de sus hijos, en la más temprana edad, y conformarlas enteramente tomando la suya como modelo».13 En el tercero, «Diálogos francos sobre temas religiosos», rechaza no la instrucción religiosa, sino la catequística, por «dar a entender a los niños que aquello que se les enseña no admite dudas. [...]. Todos los padres saben que los dogmas de su propia Iglesia son puestos en cuestión por los hombres más instruidos e ilustres. Ocultar este hecho a sus hijos es algo deshonesto». ${ }^{14}$

10 Sobre la génesis y el contenido de estos tres textos internacionales, véase Paulí Dávila Balsera y Luis M. ${ }^{a}$ Naya Garmendia, «Los derechos de los niños y niñas en los tratados internacionales. Tres momentos históricos», en Paulí Dávila y Luis M. ${ }^{a}$ Naya (coords.), La infancia en la historia: espacios y representaciones (Donostia: Erein, 2005) t. I, 889-899, y «La evolución de los derechos de la infancia: una visión internacional», Encounters on Education 7 (2006): 71-93. Como bien indican ambos autores, los textos de 1924 y 1959 son declaraciones de intenciones mientras que el de 1989 es una Convención que obliga a los Estados firmantes y cuenta con un Comité de los Derechos del Niño que vigila su cumplimiento.

11 Me refiero a «The mental rights of infants» $\mathrm{y}$ «The child's book of the soul», dos cartas escritas a John Hamilton Thom en 1836 y publicadas en Joseph Blanco White, The Life of the Rev. Joseph Blanco White, written by Himself, with Portions of his Correspondance (London, John Chapman, 1845), t. III, 375-378 y 414-422 respectivamente, y a «Plain dialogues on religion subjects», texto escrito en 1840 y publicado asimismo en el libro indicado (t. III, 436-446). Traducción y edición en castellano en José María Blanco White, Sobre educación (Madrid: Biblioteca Nueva, 2003), 209-302, 303-310 y 311-319.

12 Blanco White, Sobre educación, 301-302.

13 Blanco White, Sobre educación, 305.

14 Blanco White, Sobre educación, 315. 
Una de las fundamentaciones de la libertad de creencias de los menores procede de este derecho a una educación no dogmática sino plural, abierta a la reflexión y a la elaboración de un pensamiento propio. Otro antecedente o fundamento está constituido por la afirmación, en el ámbito educativo, de la libertad de conciencia como exigencia derivada de la libertad de ciencia o pensamiento tal y como se recogía, en 1876, en la Base $2^{\mathrm{a}}$ de los Estatutos de la Institución Libre de Enseñanza:

Esta Institución es completamente ajena a todo espíritu e interés de comunión religiosa, escuela filosófica o partido político: proclamando únicamente el principio la libertad e inviolabilidad de la Ciencia y de la consiguiente independencia de su indagación y exposición respecto de cualquier otra autoridad que la de la conciencia.

Esta libertad de conciencia no implicaba, como en ocasiones se ha dicho, una neutralidad pasiva o aséptica. Para Francisco Giner, la escuela debía excluir toda educación "confesional o dogmática», pero no el «espíritu» o «sentido religioso»; es decir, debía proporcionar una educación religiosa «no confesional, y ni aun ampliamente cristiana» basada en la «tolerancia positiva, no escéptica ni indiferente», y «la simpatía hacia todos los cultos y creencias». Era, además, desde ese pluralismo (in)formativo y educativo, basado en la libertad de conciencia, desde el que Giner se oponía al pluralismo intercentros -el modelo vigente en España según la interpretación vigente de la Constitución- por entender que dividía a la infancia en «castas mutuamente enemigas» e «incomunicadas desde la cuna». ${ }^{15}$

Una tercera fundamentación, precedente asimismo de la libertad de pensamiento, conciencia y creencias de los menores, provendría -en ese llamado ya en sus orígenes «El siglo de los niños»-16 de las ideas del movimiento internacional de la Escuela Nueva, o de la llamada educación progresiva, con su acento en la necesidad de atender a las necesidades e

\footnotetext{
15 Francisco Giner de los Ríos, «La enseñanza confesional y la escuela», Obras completas (Madrid: La Lectura, 1922), t. VII, 68-70, «La política y la escuela, según Kelsen», Obras completas (Madrid: La Lectura, 1927), t. XVI, 260, y «La verdadera descentralización en la enseñanza del Estado», Obras completas (Madrid: La Lectura, 1933), t. XII, 135 y 137.

16 Ellen Key, El siglo de los niños (estudios) (Barcelona, Heinrich y C ${ }^{a}$, 1907). Edición original de 1900 .
} 
intereses del escolar y en el derecho del menor al respeto -un concepto educativo clave- por parte de los padres y educadores. ${ }^{17}$

Reflejo de dicha orientación pedagógica serían, por ejemplo, los acuerdos adoptados por la Convención de Maestros Americanos celebrada en 1928 en Buenos Aires. En especial cuando en ellos se afirma que "todo niño tiene derecho", por un lado, "a ser "niño", a que se le respete en sus intereses, sus necesidades y su actividad espontánea y personal» y, por otro, "a "hacer" para saber, a ser descubridor y creador». ${ }^{18}$ O la Carta de los Derechos del Niño aprobada en 1929 por el grupo madrileño de la Liga Internacional de Educación Nueva que, entre los derechos de "carácter psicológico», incluía el de «ser un agente de su propia educación e instrucción» y «sentir el placer de la investigación y del descubrimiento de la verdad». Y, entre los de «carácter pedagógico», el «derecho a que se respete su futura personalidad, no imponiéndosele prematuramente ideas o concepciones de la vida que dificulten o impidan la libre formación de conciencia». ${ }^{19}$

El derecho a la libre formación de la conciencia sería retomado durante la Segunda República, junto con los del laicismo -art. 48 de la Constitución de 1931- y la neutralidad en la escuela. Primero, por la Orden de 12 de enero de 1932 que, al enviar un ejemplar de la Constitución a todas las «escuelas nacionales», determinaba los principios que debían regir la actividad escolar. Poco después, con algún matiz diferencial, en un libro escolar de autoría colectiva elaborado con el propósito de explicar la Constitución en las escuelas. La Orden ministerial ligaba el respeto a la conciencia del escolar al principio constitucional del laicismo en la enseñanza. Rechazaba en la escuela el dogmatismo y el sectarismo, así como «toda propaganda política, social, filosófica y religiosa» con el fin de no «coaccionar las conciencias», pero lo hacía desde la definición de la escuela como un «lugar neutral» que debía inhibirse «de los problemas religiosos» por ser un espacio «de todos» que aspiraba a

\footnotetext{
17 El texto fundamental sobre este último aspecto es el de Janusz Korczak, El derecho del niño al respeto. Cuando vuelva a ser niño. Diario del Ghetto (México D. F., Trillas, 1993) publicado originalmente en 1929. Sobre la relación de derechos del niño elaborada por Korczak, véase Antonio Pombo Sánchez, La derrota de la razón. Janus Korczak, médico, educador y mártir (s. l.: Xoroi Edicions, 2017), 132-134.

18 Fernando Sainz, Los derechos del niño (Madrid: CIAP, s.a.), 53.

19 Sainz, Los derechos del niño, 57-58.
} 
ser "para todos».20 El libro escolar de autoría colectiva, publicado en 1933 con el título de El Evangelio de la República. La Constitución de la Segunda República explicada a los niños, partía asimismo del mandato constitucional de la enseñanza laica derivando del mismo el principio del «respeto» tanto a la "conciencia» de los escolares como a la del docente, pero lo hacía desde una perspectiva más positiva o activa al interpretar dicho mandato no como un «concepto ofensivo» para las religiones, sino en defensa y desde el respeto a todas las creencias. Sin «libertad de conciencia», se concluía, "no hay religiosidad posible»; es decir, no hay libertad religiosa. ${ }^{21}$

\section{LA CONVENCIÓN DE 1989 Y LOS DERECHOS MENTALES, (IN)FORMATIVOS Y EDUCATIVOS DE LOS MENORES}

La Convención de 1989 retoma y se basa en parte, entre otros, en los principios que sustentan los antecedentes mencionados..$^{22}$ Pero va más allá. Significa el paso de la consideración del menor no como un adulto en miniatura, o solo en fase de transición a la vida adulta, sino como un ser humano con sus aspiraciones, deseos, intereses y necesidades específicas. Y, como consecuencia, añade a la idea de protección-que, como es obvio, persiste, se actualiza y refuerza- la de autonomía, constituyendo al menor no ya como objeto de derechos y obligaciones -que también-, sino como sujeto o titular de derechos y obligaciones propias, cuyo desarrollo evolutivo y ejercicio debe ser tutelado por los poderes públicos y guiado por los padres o tutores: «el niño o la niña no pertenecen a su familia ni al Estado, se pertenece a sí mismo».23 Es en este sentido en el que puede afirmarse que la Convención de 1989 constituye un hito en el progresivo "carácter puerocéntrico del Derecho», apreciable

\footnotetext{
20 Historia de la Educación en España. IV. La educación durante la Segunda República y la Guerra Civil (1931-1939) (Madrid: Ministerio de Educación y Ciencia, 1991), 165.

21 Historia de la Educación en España. IV. La educación durante la Segunda República y la Guerra Civil (1931-1939), 335-336.

22 Para una visión general de la Convención de 1989 -antecedentes, génesis, contenido, principios rectores, aspectos susceptibles de crítica, reservas y aplicación, etc.-, véase Paulí Dávila Balsera y Luis María Naya Garmendia, «La infancia en Europa: una aproximación a partir de la Convención de los Derechos del Niño», Revista Española de Educación Comparada 9 (2003): 83-133.

23 UNICEF - Comité País Vasco, «El concepto de niño: de objeto a sujeto de derechos», en Paulí Dávila y Luis M. ${ }^{a}$ Naya (coords.), La infancia en la historia: espacios y representaciones (Donostia: Erein, 2005), t. I, 905.
} 
durante las "últimas décadas del siglo XX», origen de "una nueva materia o campo jurídico con entidad propia: el derecho del menor». ${ }^{24}$

¿Qué derechos mentales, educativos e (in)formativos de los menores recoge la Convención de 1989? ¿Cuál es la función y papel de los padres en esa nueva concepción de la infancia y de la minoridad? ¿Qué cuestiones planteó su génesis y firma? ¿Cuál es su vigencia y estatus legal en el ordenamiento jurídico español?

La Convención comienza (art. 1) con una clarificación necesaria: se entiende por «niño todo ser humano menor de dieciocho años de edad, salvo que, en virtud de la ley que le sea aplicable, haya alcanzado antes la mayoría de edad». Con ello viene a identificar infancia con minoridad, y niño o niña con el o la menor de edad.

Los derechos-libertades mentales de los menores establecidos por la Convención constituyen, en síntesis, una actualización ampliada de los anteriormente expuestos a título de antecedente. En primer lugar, la «libertad de expresión» que incluye el derecho a recibir una información plural o «libertad de buscar, recibir, y difundir informaciones e ideas de todo tipo, sin consideración de fronteras, ya sea oralmente, por escrito o impresas, en forma artística o por cualquier otro medio elegido por el niño» (art. 13-1). En esta misma línea, y en relación con «los medios de comunicación», se establece que los Estados «velarán porque el niño tenga acceso a información y material de diversas fuentes nacionales e internacionales, en especial la información y el material que tengan por finalidad promover su bienestar social, espiritual y moral y su salud física y mental» (art. 17). Un deber estatal que implica una acción positiva que va más allá de su ámbito estricto de actuación. En otro caso, sería ineficaz y carecería de sentido.

En segundo lugar, la Convención reconoce a los menores una serie de derechos-libertades cuya inclusión solo viene a reforzar las que ya les estaban reconocidas, como tales seres humanos, por la DUDH de 1948: «la libertad de pensamiento, de conciencia y de religión» (art. 14-1), ${ }^{25}$ «la

\footnotetext{
24 Belén Rodrigo Lara, «El menor de edad y su derecho de libertad religiosa como agentes determinantes del interés superior del niño", Anuario de Derecho Eclesiástico del Estado XXXV (2019): 357.

$25 \mathrm{El}$ «derecho a la libertad de conciencia, de pensamiento y de religión, sin perjuicio de las responsabilidades que las legislaciones nacionales reserven a estos ámbitos a los padres o personas
} 
libertad de profesar la propia religión o las propias creencias» (art. 143) y las libertades «de asociación» y «de celebrar reuniones pacíficas» (art. 15.1).

En tercer lugar, como complemento y en concordancia con lo anterior, se declara como derecho-deber de los «padres» y, en su caso, «representantes legales», "guiar al niño en el ejercicio de su derecho [a la libertad de pensamiento, conciencia y religión] de modo conforme a la evolución de sus facultades» (art. 14.2), una concreción de su derecho-deber general de dirigir y orientar de forma apropiada al menor para que este «ejerza los derechos reconocidos en la presente Convención» (art. 5). En otras palabras, los padres y tutores legales guían, dirigen y orientan al menor, con el fin de prepararle para el ejercicio progresivo de sus derechos y libertades. Una tarea en la que «su preocupación fundamental será el interés superior del niño» (art. 18.1). Un «interés superior», el del menor, reiterado una y otra vez en la Convención (arts. 3.1, 9.1, 18.1, 37.c y 40.2.b.iii) que se sobrepone y prima sobre cualquier otro.

En cuarto y último lugar, la Convención regula otros dos aspectos además del relativo de modo específico al derecho a la educación (art. 28) - que afectan a sus derechos educativos o limitan la libertad de creación de centros docentes por particulares o entidades. En el primer caso, los Estados «garantizarán» al menor, «que esté en condiciones de formarse un juicio propio, el derecho de expresar su opinión libremente en todos los asuntos» que le afectan, "teniéndose debidamente en cuenta» sus «opiniones [...], en función de la edad y madurez» del mismo (art. 12.1), en especial «en todo procedimiento judicial o administrativo» que le afecte (art. 12.2). Es decir, en todo lo relativo, entre otras cuestiones, a sus estudios, formación y educación. ${ }^{26}$

En el segundo caso, primero se establece el ideario educativo o fines a los que deberá estar encaminada la educación de los menores (art. 29.1):

encargadas de los mismos», figura asimismo en la Carta Europea de Derechos del Niño de 21 de septiembre de 1992 (art. 18).

26 La LOMCE de 2013 incumplía dicho precepto en dos ocasiones: en la incorporación del alumnado de la Educación Secundaria Obligatoria a los programas de mejora del aprendizaje y del rendimiento (art. 27.2) y a la Formación Profesional Básica (art. 41.1.c). En ambos casos, se atribuía la decisión a los padres o tutores sin siquiera dar audiencia al menor. 
a) Desarrollar la personalidad, las aptitudes y la capacidad mental y física del niño hasta el máximo de sus posibilidades.

b) Inculcar al niño el respeto de los derechos humanos y las libertades fundamentales y de los principios consagrados en la Carta de las Naciones Unidas.

c) Inculcar al niño el respeto de sus padres, de su propia identidad cultural, de su idioma y sus valores, de los valores nacionales del país en que vive, del país que sea originario y de las civilizaciones distintas a la suya.

d) Preparar al niño para asumir una vida responsable en una sociedad libre, con espíritu de comprensión, paz, tolerancia, igualdad de sexos y amistad entre todos los pueblos, grupos étnicos, nacionales y religiosos, y personas de origen indígena.

e) Inculcar al niño el respeto del medio ambiente natural.

Y de inmediato, como límite a la libertad de creación y dirección de «instituciones de enseñanza» por particulares y entidades, se establece la condición de que «se respeten los principios» de dicho ideario educativo (art. 29.2).

La cuestión de la libertad de pensamiento, conciencia y religiosa de los menores, introducida a propuesta de Estados Unidos, fue una de las más controvertidas tanto en la elaboración como en la firma del Convenio, llegando incluso a poner en cuestión su aprobación. ${ }^{27}$ Al final la Convención fue aprobada, pero 18 países la firmaron con reservas relativas todas ellas a los derechos reconocidos a los menores en los artículos 12 a 17 y, en especial, a la libertad de pensamiento, conciencia y religión (art. 14.1). En su mayor parte se trataba de países árabes que aducían, en síntesis, que dichas libertades se oponían al derecho islámico o cherámico, a la legislación estatal y, en definitiva, al derecho, usos y costumbres de educar a los menores en la religión de sus padres. El Estado polaco indicó que, en todo caso, los derechos enunciados en los artículos 12 a 17 se ejercerían «con respeto de la

\footnotetext{
27 María Cebriá García, «El derecho a la libertad religiosa del menor: problemas que plantea», Anuario de la Facultad de Derecho. Universidad de Extremadura 19-20 (2001-2002), 137. Posteriormente, sin embargo, Estados Unidos, junto con Somalia, no firmó la Convención una vez aprobada. La relación de países firmantes distinguiendo aquellos que, en aquel momento, la habían ratificado o adherido a ella, o solo la habían firmado, figura al final del Instrumento de ratificación publicado en el Boletín Oficial del Estado (BOE) de 31 de diciembre de 1990, n. ${ }^{\circ} 313$, pp. 38903-38904.
} 
patria potestad, de conformidad con las costumbres y tradiciones polacas sobre la posición del niño dentro y fuera de la familia». Y el Estado del Vaticano se reservó el derecho de interpretar la Convención de manera que se salvaguardaran «los derechos primarios e inalienables de los padres, en particular, entre otros, los derechos que conciernen a la religión». ${ }^{28}$ La posición del Vaticano era, y sigue siendo, plenamente coherente con el derecho y "gravísimo deber» de educar a sus hijos «según la doctrina enseñada por la Iglesia», impuesto a los «padres cristianos» -léase católicos- en los cánones 226.2 y 1136 del Código de Derecho Canónico.

El Estado español no solo firmó la Convención el 26 de enero de 1990, sino que la ratificó el 30 de noviembre de dicho año, con una matización y una discrepancia sin relación alguna con el tema aquí tratado, siendo publicada en el Boletín Oficial del Estado el 31 de diciembre de 1990. De este modo ha pasado a formar parte, como tratado o convención internacional, del ordenamiento jurídico español, tal y como estipulan los artículos 39.4 y 96.1 de la Constitución española (CE), y así ha sido desarrollada tanto por la Ley Orgánica de Protección Jurídica del Menor (LOPJM) de 15 de enero de 1996 modificada posteriormente por Ley de 28 de julio de 2015, como por la legislación autonómica.

Asimismo, se incorpora a la Constitución de 1978 -es decir, adquiere rango constitucional- por una doble vía. Primero, como acuerdo internacional ratificado por España, alcanza el carácter de norma a tener en cuenta en la interpretación de «los derechos fundamentales» y «las libertades que la Constitución reconoce» (art. 10.2 CE), entre ellos el «derecho que asiste a los padres para que sus hijos reciban la formación religiosa y moral que esté de acuerdo con sus propias convicciones» (art. 27.3 CE), y «la libertad de creación de centros docentes» (art. 27.6 CE). En otras palabras, el párrafo de la Constitución que fue introducido en el Senado por la Unión de Centro Democrático para reforzar y garantizar justamente estos dos derechos -como se detalló en la primera parte de este ensayo-, obliga ahora a tener en cuenta, al mismo nivel constitucional, una serie de derechos y libertades -los reconocidos a los menores por la Convención de 1989- cuyo encaje o compaginación con los

28 Cebriá García, «El derecho a la libertad religiosa del menor», 137-138. 
mencionados, entre otros, resulta al menos problemático y limitativo por no decir conflictivo. En segundo lugar, la Convención de 1989 se incorpora al bloque normativo constitucional de modo directamente aplicable y sin necesidad de recurrir a la vía interpretativa, en virtud del art. 39.2 CE donde se establece que «los niños gozarán de la protección prevista en los acuerdos internacionales que velan por sus derechos». Pese a todo ello, una parte de la doctrina, de los organismos legisladores y de la judicatura hasta el más alto nivel, opta, a nuestro juicio, por seguir escribiendo, legislando o juzgando como si dicha Convención no existiera o no tuviera nada que ver con los derechos y libertades relativas a la enseñanza o con otros derechos y libertades fundamentales como la libertad religiosa, entre otras.

\section{LA LEY ORGÁNICA DE PROTECCIÓN JURÍDICA DEL MENOR DE} 15 DE ENERO DE 1996

Con independencia de lo anterior, la Convención de 1989 ha sido desarrollada en España por la LOPJM de 15 de enero de 1996. Su Exposición de Motivos recoge perfectamente el cambio y los nuevos aires aportados por la misma: 29

Las transformaciones sociales y culturales operadas en nuestra sociedad han provocado un cambio en el status social del niño y, como consecuencia de ello, se ha dado un nuevo enfoque a la construcción del edificio de los derechos humanos de la infancia.

Este enfoque reformula la estructura del derecho a la protección a la infancia vigente en España y en la mayoría de los países desarrollados desde finales del siglo XX, y consiste fundamentalmente en el reconocimiento pleno de la titularidad de los derechos en los menores de edad y de una capacidad progresiva para ejercerlos.

De acuerdo con ello, continua diciendo la Exposición, la nueva ley introduce «la condición de sujeto de derechos a las personas menores de

\footnotetext{
29 Los cambios introducidos por la Ley de 28 de julio de 2015, «de modificación del sistema de protección a la infancia y adolescencia», no afectan a las cuestiones aquí tratadas. En lo que a la educación se refiere, solo se modificaron, en la Disposición final séptima, los criterios establecidos en la LOMCE de 2013 para la admisión de alumnos en los centros docentes.
} 
edad», así como «la dimensión en el desarrollo evolutivo en ejercicio de sus derechos», promoviendo "su autonomía como sujetos [...] activos, participativos y creativos, con capacidad de modificar su propio medio personal y social» a fin de que puedan ir «construyendo progresivamente una percepción de control acerca de su situación personal y de su proyección de futuro».

Siguiendo el espíritu y la letra de la Convención de 1989, la LOPJM dedica un extenso artículo 2 al «interés superior del menor» declarando de modo específico su «derecho» a que dicho «interés superior sea valorado y considerado primordial en todas las acciones y decisiones que le conciernan, tanto en el ámbito público como privado». En cuanto a los derechos y libertades mentales, educativos e (in)formativos, se establecen y regulan:

a) El «derecho a buscar, recibir y utilizar la información adecuada a su desarrollo», prestándose «especial atención a la alfabetización digital y mediática». En cuanto a la información que reciban -y esto es lo más relevante- tanto «los padres o tutores» como «los poderes públicos velarán» que sea «veraz, plural y respetuosa con los principios constitucionales» (art. 5). Retengamos el principio de pluralidad informativa como obligación-deber de los padres o tutores y de los poderes públicos.

b) El «derecho a la libertad de ideología, conciencia y religión. [...] Los padres y tutores tienen el derecho y el deber de cooperar para que el menor ejerza esta libertad de modo que contribuya a su desarrollo integral» (art. 6).

Tres observaciones: a) se sustituye el término «pensamiento» de la Convención de 1989 por el de «ideología», a mi juicio más polisémico; b) como ya sucedía en la citada Convención, no se trata de tres libertades diferentes, sino de una única libertad, en singular; y c) los verbos guiar y dirigir utilizados en la Convención para caracterizar la función-deber de los padres y tutores en relación con el desarrollo del ejercicio de estas y otras libertades o derechos del menor, se sustituyen por el de cooperar.

Y dos comentarios. El primero es que considero más completa y acertada la redacción del artículo 19 de la Ley de la Generalidad Valenciana, 
de 21 de diciembre de 2018, de «derechos y garantías de la infancia y la adolescencia»:

Las personas progenitoras y tutoras, en el desempeño de su derecho y deber de cooperar en el ejercicio del derecho de niños, niñas y adolescentes a la libertad de ideología, conciencia y religión, escucharán sus opiniones, fomentarán el desarrollo de un criterio propio y respetarán sus convicciones.

El segundo es que el respeto a la libertad de conciencia y a las convicciones religiosas y morales del alumnado «de acuerdo con la Constitución», figura en nuestra legislación desde la Ley Orgánica del Derecho a la Educación (LODE) de 1985 -art. 6, 3. ${ }^{\circ}$ f)-, sin que dicho reconocimiento haya tenido desarrollo o efecto alguno desde el punto de vista práctico, legal o judicial. Nada extraño si se tiene en cuenta que esa misma legislación, como se verá, contradice en más de una ocasión dicho deber de respeto.

c) Los derechos de participación plena «en la vida social, cultural, artística y recreativa de su entorno», de incorporación "progresiva a una ciudadanía activa», de «asociación» y de participación «en reuniones públicas y manifestaciones pacíficas» (art.7).

d) La «libertad de expresión» (art. 8).

e) El «derecho a ser oído y escuchado [...], tanto en el ámbito familiar como en cualquier procedimiento administrativo, judicial o de mediación en que esté afectado y que conduzca a una decisión que incida en su esfera personal, familiar o social, teniéndose debidamente en cuenta sus opiniones en función de su edad y madurez» (art. 9).

Los derechos mentales, educativos e (in)formativos de los menores están pues reconocidos en el ordenamiento jurídico español tanto a nivel constitucional, desde la ratificación el 30 de noviembre de 1990 de la Convención de 1989, como en su desarrollo legislativo, en este caso desde la publicación en el BOE, el 17 de enero de 1996, de la LOPJM de 15 de enero de dicho año. Queda por ver cómo han sido interpretados y aplicados judicialmente, así como el tratamiento doctrinal de los mismos. Pero 
antes es necesario aclarar algunas cuestiones relativas a la naturaleza y límites del derecho de los padres a que sus hijos reciban la formación religiosa y moral que esté de acuerdo con sus convicciones, a la función, papel y asimismo límites de la acción de los poderes públicos en esta cuestión y, cómo no, al alcance y virtualidad de la libertad de pensamiento, conciencia y religión de los menores.

\section{EL DERECHO DE LOS PADRES A QUE SUS HIJOS RECIBAN LA FORMACIÓN RELIGIOSA Y MORAL ACORDE CON SUS CONVICCIONES (ART. 27-3 CE): NATURALEZA, TITULARIDAD Y LÍMITES}

El derecho reconocido a los padres en el art. 27-3 de la CE tiene, bajo esa redacción u otras similares, un fuerte respaldo en los tratados y acuerdos internacionales. En unos se habla, de modo más amplio, del derecho "preferente a escoger el tipo de educación que habrá de darse a sus hijos» (art. 26.3 de la DUDH de 1948) o del derecho a «la educación y la enseñanza de sus hijos conforme a sus convicciones religiosas, filosóficas y pedagógicas»-art. 14.3 de la Carta de Derechos Fundamentales de la Unión Europea de 1990- y, en otros, se limita dicho derecho, como en la $\mathrm{CE}$, a la «educación religiosa y moral» (arts. 18 del Pacto Internacional de Derechos Civiles y Políticos y 13.3 del Pacto Internacional de Derechos Económicos, Sociales y Culturales de 1996). ¿Cómo casar este derecho con el de los menores a la libertad de pensamiento, conciencia y religión? La misma Carta Europea de Derechos del Niño de 21 de septiembre de 1992, tras reconocer dicha libertad en su artículo 18 añade que ello se hace «sin perjuicio de las responsabilidades que las legislaciones nacionales reserven a estos ámbitos a los padres o personas encargadas de los mismos». Una manera elegante de curarse en salud sin abordar el problema y dejando a los legisladores y tribunales de cada país su solución práctica. Es decir, el ejercicio efectivo de dicha libertad por los menores.

El problema se ha planteado desde el punto de vista judicial cuando los deseos de los padres divergen entre sí, o se oponen al bienestar de los hijos -sea lo que sea o cómo se interprete dicho bienestar- o a las preferencias $\mathrm{u}$ opciones de estos últimos cuando poseen ya un grado de madurez suficiente para formarlas y expresarlas. También en aquellos 
casos en los que la legislación educativa de cada Estado choca con las convicciones religiosas o morales de los padres. De un modo u otro, ello ha obligado a la doctrina -profesionales del derecho que reflexionan y escriben sobre estas cuestiones- y a los jueces a plantearse cuál es la naturaleza del mencionado derecho de los padres, y si dicho derecho posee algún tipo de límite como consecuencia del que sus hijos tienen a la libertad de pensamiento, conciencia y religión o viceversa.

\section{Naturaleza y extensión}

En cuanto a la naturaleza y extensión de este derecho parental, conviene primero precisar que se entiende por «convicciones». El Tribunal Europeo de Derechos Humanos (TDEH) ha entendido que este término hay que interpretarlo en conexión con la libertad de pensamiento, conciencia y religión, y que es no sinónimo de cualesquiera opiniones o ideas por requerir «un cierto grado de fuerza, seriedad, coherencia y relevancia». ${ }^{30}$ En palabras_de Meix Cereceda, se trataría, en todo caso de ideas «dignas de respeto en una sociedad democrática y compatibles con la dignidad humana». Su función en el sistema educativo, sería la de «potenciar el pluralismo [...] y erradicar cualquier adoctrinamiento contrario a la convivencia democrática». ${ }^{31}$

Clarificada esta cuestión previa, son varias las controversias doctrinales y judiciales. En primer lugar, ¿abarca solo la formación religiosa y moral o también las convicciones ideológicas, filosóficas y pedagógicas, como se indica en el art. 14.3 de la Carta de Derechos Fundamentales de la Unión Europea? El Tribunal Supremo (TS) en sentencia de 11 de febrero de 2009 entendió que dicho derecho se refiere «al mundo de las creencias y de los modelos de conducta individual que, con independencia de respetar esa moral común subyacente en los derechos fundamentales, cada persona es libre de elegir para sí y de transmitir a sus hijos».32 Sin embargo, el TC en la sentencia 133/2010, de 2 de diciembre, sobre el

\footnotetext{
30 Beatriz Souto Galván, «La libertad de creencias del menor», Revista Europea de Derechos Fundamentales 28 (2015): 199.

31 Pablo Meix Cereceda, El derecho a la educación en el sistema internacional y europeo (Valencia: Tirant lo Blanch, 2014), 77 y 78.

32 Beatriz Souto Galván, Educación y creencias. Nuevas y viejas cuestiones sobre querellas educativas (Madrid: Dykinson, 2012), 26-27.
} 
homeschooling, entendió que ese derecho no incluye el de elegir el tipo de educación que en este caso se deseaba para los hijos -la enseñanza en el hogar-, por encontrar dicho derecho el límite del deber constitucional de la escolarización obligatoria.

Sigamos: ¿incluye o no la libertad de elección de centro docente? ¿Estamos ante un derecho prestacional y, por tanto, ante la obligación estatal de crear disciplinas específicas, de índole confesional, para formar al alumnado en las convicciones religiosas y morales de los padres, o los poderes públicos han de limitarse, en este punto, a garantizar dicha formación en el ámbito familiar, en lugares propios de cada confesión religiosa o incluso en locales de centros docentes públicos fuera del horario escolar y a cargo, en todos los sentidos, de cada confesión religiosa o grupo social con unas creencias determinadas? ${ }^{33}$ ¿Se trata de un derecho-función o de un derecho-libertad? Si se conceptúa como un derecho-función, «la finalidad perseguida por los padres con el ejercicio del derecho sería el interés del menor que, de este modo, vendría a ser objeto y, a la vez, límite del ejercicio»; sin embargo, si se trata de un derecho-libertad su «ejercicio persigue satisfacer el interés paterno, no el de los hijos", que los padres pueden o no ejercer ya que se fundamenta no en la titularidad de la patria potestad -en tal caso, sería un derecho-deber- sino en su libertad religiosa. ${ }^{34}$ Esta última distinción nos lleva a los debates sobre su titularidad y, como consecuencia, sus límites.

\section{Titularidad}

En este punto, las controversias e interpretaciones divergentes en función de la cosmovisión, ideología o concepción del mundo y de la vida del tratadista o juez, aparecen de nuevo. Para unos, estamos ante un auténtico derecho de los padres en su propio interés y en defensa de la unidad familiar. Otros atribuyen el derecho a los hijos si bien los padres lo ejercen de hecho por representación cuando los menores no han

\footnotetext{
33 Souto Galván, Educación y creencias, 30-31.

34 Miguel Ángel Asensio Sánchez. «Libertad religiosa del menor y relaciones paterno-filiales: conflictos». Revista Española de Derecho Canónico 72 (2015): 22-23. Esta segunda opción es la que, a juicio del autor, «mejor responde a nuestra realidad legislativa y, por eso, entendemos que cuando los padres eligen la educación religiosa de los hijos o deciden bautizarlos, están ejerciendo su propio derecho de libertad religiosa y no una de las funciones inherentes a la patria potestad; tampoco puede entenderse como un ejercicio por representación del derecho a la libertad religiosa del menor» (p. 15).
} 
alcanzado el grado de madurez suficiente para ejercerlo personalmente, circunstancia que según el ordenamiento jurídico español deberá ser apreciada, en cada caso, por el juez o jueces de turno. Para otros, se trataría de un derecho-deber: derecho frente al Estado y deber en relación con los hijos y sus intereses. ${ }^{35}$

Dentro de esta última interpretación hay asimismo amplias divergencias en cuanto al alcance de este deber y de cuáles sean dichos intereses o, en último término, cuál es el interés, siempre superior, del menor. Hay quienes, establecido dicho deber en interés del menor, entienden que ello no empece la acción de proselitismo sobre el mismo introduciéndole en los ritos, prácticas y creencias de una confesión religiosa determinada prácticamente desde su nacimiento, ${ }^{36}$ y quienes, por el contrario, sostienen que el carácter personalísimo del derecho de libertad religiosa o de creencias de los menores convierte en «abusivo» y legalmente «ilícito» el hecho de que los padres adopten decisiones de transcendencia religiosa como las indicadas, aunque paradójicamente haya casos en que un mismo autor entienda que el derecho a la libertad religiosa o de creencias de los menores actúa, en este sentido, como límite a la libertad religiosa de los padres (art. 16-1 CE), pero no al derecho a que los hijos reciban una formación religiosa y moral determinada en el ámbito escolar (art. 27.3 CE).37

\section{Límites}

Todos los derechos, incluidos los fundamentales son limitados, ya lo sea por razones intrínsecas, derivadas de su mismo contenido, o extrínsecas, por su «encuentro y colisión con otros». ${ }^{38}$ El derecho parental a que los hijos reciban una formación religiosa y moral acorde con sus convicciones tiene al menos tres límites.

\footnotetext{
35 María Rosa García Vilardell, «La libertad de creencias del menor y las potestades educativas paternas: la cuestión del derecho de los padres la formación religiosa y moral de sus hijos». Revista Española de Derecho Canónico 66 (2009): 339-342 y 346-349.

36 García Vilardell, «La libertad de creencias del menor», 340-342, entre otros autores.

37 Francisco Rivero Hernández, «Límites de la libertad religiosa y las relaciones personales de un padre con sus hijos (Comentario de la STC 141/2000, de 29 de mayo)», Derecho Privado y Constitución 14 (2000): 267-269.

38 Rivero Hernández, «Límites de la libertad religiosa», 246.
} 
Uno de ellos, en el caso español, es el ya mencionado de la obligatoriedad de la escolarización básica (art. 27.4 CE) y, por tanto, la no constitucionalidad de la llamada «enseñanza en el hogar». Vale la pena transcribir -por su defensa implícita del pluralismo intracentros frente al intercentros judicialmente impuesto en otras sentencias- aquellos párrafos de la sentencia del TC 133/2010, de 2 de diciembre, en los que se fundamenta la decisión adoptada:

La educación a la que todos tienen derecho [...] no se contrae [...] a un proceso de mera transmisión de conocimientos [...], sino que aspira a posibilitar el libre desarrollo de la personalidad y de las capacidades de los alumnos [...] y comprende la formación de ciudadanos responsables llamados a participar en los procesos que se desarrollan en una sociedad plural [...] en condiciones de igualdad y tolerancia, y con pleno respeto a los derechos y libertades fundamentales del resto de sus miembros [...].

[...] Este objetivo, complejo y plural, es el que conforme al art. 27.2 CE, ha(n) de perseguir el legislador y el resto de los poderes públicos a la hora de configurar el sistema de enseñanza dirigido a garantizar el derecho de todos a la educación, y el mandato de su consecución es el principio constitucional al que sirve la imposición normativa del deber de escolarización en el marco de la enseñanza básica obligatoria. [...]

[...] el sistema educativo en general y la enseñanza básica en particular [...] han de servir también a la garantía del libre desarrollo de la personalidad individual en el marco de una sociedad democrática y a la formación de ciudadanos respetuosos con los principios democráticos de convivencia y con los derechos y libertades fundamentales, una finalidad ésta que se ve satisfecha más eficazmente mediante un modelo de enseñanza básica en el que el contacto con una sociedad plural y con los diversos y heterogéneos elementos que la integran, lejos de tener lugar de manera puramente ocasional y fragmentaria, forma parte de la experiencia cotidiana que facilita la escolarización. ${ }^{39}$

39 Sentencia del TC 133/2010, de 2 de diciembre, BOE 5 de enero de 2011: 121-122. 
Tal y como se desprende de los párrafos anteriores, la existencia de un ideario constitucional educativo y político (arts. 27.2, 1.1 y 9.2 CE), es decir, de una Constitución «militante», supone un segundo límite al derecho parental establecido en el art. 27.3 CE. Y no solo porque excluya entre las opciones posibles el modelo de educación de la «enseñanza en el hogar»-aunque se base en razones religiosas y morales-, sino porque el tipo de formación religiosa y moral por el que opten los padres para educar a sus hijos encuentra el límite de dicho ideario político-educativo constitucional; es decir, del derecho del menor a una educación democrática que promueva la igualdad, el pluralismo y la libertad como valores éticos. El derecho a la educación no es, por tanto, constitucionalmente «neutral desde un punto de vista moral y debe orientarse -positivamente-a la impregnación del educando de ciertos valores que constituyen una moral cívico-democrática, deshaciendo cualquier equívoco respecto a la posible neutralidad axiológica del Estado en la tarea educativa del Estado». ${ }^{40}$

El tercer límite al derecho de los padres a que sus hijos reciban una formación religiosa y moral acorde con sus convicciones procede no ya del derecho a la educación del menor, sino de su derecho a la libertad de pensamiento, conciencia y religión introducida en nuestra Constitución desde la firma y ratificación por España de la Convención de 1989. Una sola libertad -no tres libertades distintas sin relación entre sí- que un sector doctrinal sintetiza, en una sola palabra, como libertad de creencias. Un derecho-libertad que, en caso de conflicto con otros derechos y libertades -entre ellos los de los padres-, debe ser interpretado de acuerdo con la prevalencia del «interés superior del menor».

\section{LA LIBERTAD DE PENSAMIENTO, CONCIENCIA Y RELIGIÓN DEL MENOR}

La tesis o interpretación doctrinal y judicial de que la libertad de creencias del menor solo puede ser ejercida personal y directamente cuando alcance un grado de madurez suficiente, plantea al menos dos cuestiones: una es la actitud y comportamiento de los padres con anterioridad a dicho momento en relación con su derecho-deber de preparar

\footnotetext{
40 Benito Aláez Corral, «El ideario educativo constitucional como límite a las libertades educativas»,
} Revista Europea de Derechos Fundamentales 17 (2011): 124. 
al menor para el ejercicio de dicha libertad; otra es la determinación del ese momento. Por lo que se refiere a la libertad religiosa -«inmunidad de coacción en materia religiosa», libertad para tener o cambiar de religión y para realizar las actividades que conlleva su pertenencia a una u otra, ...-, ${ }^{41}$ hay ocasiones en las que la legislación de cada país determina dicho momento. Portugal y Suiza, por ejemplo, fijan la edad de 16 años, Finlandia 15 e Italia y Alemania 14. En España nada se dice al respecto, si bien para otras cuestiones -matrimonio, contrato laboral, emancipación, ...- suele fijarse una edad que oscila entre los 14 y los 16 años, edades normalmente admitidas por la doctrina en relación con el ejercicio por el menor de la libertad religiosa, aunque en algún caso haya quien proponga los 12 años. ${ }^{42}$ Queda, por tanto, a los tribunales de justicia apreciar, en cada caso, si el menor posee el grado suficiente de madurez para ejercer la libertad religiosa entendida del modo restrictivo que acaba de decirse. Es decir, más como una libertad confesional que como una libertad integrada en las de pensamiento y conciencia formando parte de la más amplia libertad de creencias. Al enfocarse la cuestión desde esta perspectiva confesional queda sin resolver el tema de la libertad de pensamiento, conciencia y creencias de los menores antes de la edad en que se considere, por el legislador o los tratadistas y jueces, que poseen madurez suficiente para ejercerla por sí mismos.

En efecto, si se acepta la interpretación de que antes de dicha edad la inserción del menor en una confesión religiosa es un derecho parental derivado de su libertad religiosa, sin más límites que los genéricos que el ordenamiento jurídico del país establezca para el ejercicio de todo derecho o libertad, la conclusión es que, en el fondo, se está aplicando de hecho, para el período anterior a la mencionada edad, la misma reserva que hicieron a la Convención de 1989 aquellos países que estimaron que su legislación, usos y costumbres reconocían a los padres el derecho de inculcar a sus hijos sus convicciones religiosas. En otras palabras, cuando hablamos del derecho-libertad de los padres para educar a sus hijos en dichas convicciones ¿estamos hablando de

\footnotetext{
41 Cebriá García, «El derecho a la libertad religiosa del menor», 141.

42 Cebriá García, «El derecho a la libertad religiosa del menor», 142-146; Ángeles Liñán García, «La protección jurídica del menor: especial incidencia de la esfera familiar en su derecho de libertad religiosa y conciencia», Anales de Derecho 32 (2014): 11-12; María José Redondo Andrés, "La libertad religiosa del menor». Anuario de Derecho Eclesiástico del Estado 20 (2004): 138-139.
} 
un derecho-libertad absoluto o de un derecho-libertad limitado por el que asimismo los menores tienen, desde su nacimiento, a la libertad de pensamiento, conciencia y religión que, repito, se trata de una libertad única, comprendida en la libertad de creencias, en la que no es posible disociar ninguna de sus partes?

La cuestión planteada requiere precisar qué se entiende por dicha libertad. En este punto son clarificadoras las palabras de Martha Nussbaum cuando analiza y defiende lo que ella llama «la tradición estadounidense de libertad religiosa». La conciencia es definida, de acuerdo con dicha tradición, como «la capacidad de buscar sentido en la vida. [...] un aspecto [...] de la dignidad humana», o como un "espacio protegido a su alrededor dentro del cual las personas puedan emprender su búsqueda del sentido de la vida (o no emprenderla, si así lo deciden)» que el Estado debe garantizar. ${ }^{43}$ También como la «sede de la imaginación, la emoción, el pensamiento y la voluntad, mediante la cual toda persona busca el sentido de las cosas a su propia manera. [...] una exploración arriesgada y solitaria [...] sin interferencias del Estado ni de la religión ortodoxa. Imponer una ortodoxia a la conciencia equivale a lo que Williams [...] denominó una "violación del alma" ». La «conciencia», en suma, «no es invulnerable: puede ser dañada y aplastada, y necesita espacio para desarrollarse», o sea, «respeto». ${ }^{44}$

Esta concepción de la conciencia afecta, por lo que a los menores se refiere, tanto al Estado como a los padres. El Estado, nos dice Nussbaum, "puede instruir en la diferencia religiosa y su historia; puede familiarizar a los alumnos con la multiplicidad de religiones [...]; y puede transmitir como verdadero, y digno de amor, el principio de igual respeto por la conciencia». ${ }^{45}$ Esta sería, por ejemplo, la línea seguida por la Carta Europea de los Derechos del Niño de 21 de septiembre de 1992. Tras reconocer, en su artículo 18, el derecho del menor «a la libertad de conciencia, de pensamiento y de religión, sin perjuicio de las responsabilidades que

\footnotetext{
43 Martha Nussbaum, Libertad de conciencia. En defensa de la tradición estadounidense de libertad religiosa (Barcelona: Tusquets, 2009), 233 y 31.

44 Nussbaum, Libertad de conciencia, 47, 63 y 78. Las referencias las toma Nussbaum de la obra de Roger Williams, The Bloudy Tenent of the Persecution (1644) y The Bloudy Tenent yet More Bloudy (1652).

45 Nussbaum, Libertad de conciencia, 331.
} 
las legislaciones nacionales reserven a estos ámbitos a los padres o personas encargadas de los mismos», continúa diciendo que:

con el fin de proteger a los menores, conviene un control más estricto de las actividades de las sectas o nuevos movimientos religiosos que puedan tener repercusiones negativas en el ámbito educativo, cultural y social de los niños, y hace suya la Recomendación 1178 del Consejo de Europa de 5 de febrero de 1992 que exige en particular: que el programa del sistema general de educación comprenda una información concreta sobre las religiones más importantes y sus principales variantes, sobre los principios del estudio comparativo de las religiones y sobre la ética y los derechos personales y sociales.

Es decir, por un lado, los poderes públicos deben proteger a los menores frente al considerado «proselitismo abusivo» de las «sectas y nuevos movimientos religiosos»-por lo general a causa de la pertenencia del padre y/o la madre a dichos movimientos-. ${ }^{46}$ Por otro, deben promover políticas educativas activas que faciliten el conocimiento y respeto de otras creencias. Es decir, implantar, en lo que a la educación religiosa se refiere, un modelo integrado y plural, que eduque en la diversidad, el conocimiento y el respeto de las diversas creencias, frente al modelo segregado donde cada confesión religiosa instruye por separado a los que pertenecen a ella. ${ }^{47}$

\footnotetext{
46 Liñán García, «La protección jurídica del menor», 22. No está de más indicar que, por lo general, todas las religiones y creencias pueden considerarse en sus comienzos como sectas -«Doctrina religiosa o ideológica que se aparta de lo que se considera ortodoxo», según la primera acepción del diccionario de la Real Academia Española-, o poseen en sus orígenes rasgos propios de las sectas o grupos minoritarios. El mismo cristianismo nace como una secta o grupo minoritario del judaísmo -se ha estimado que hacia el año 50 los cristianos solo eran unos 1.400 (Rodney Stark, La expansión del cristianismo. Un estudio sociológico (Madrid: Trotta, 2009), 19- y, en sus tres primeros siglos, se conformó como una religión con muy diversos grupos-sectas en conflicto entre sí por imponer a los demás su ortodoxia -Antonio Piñero, Los cristianismos derrotados ¿Cuál fue el pensamiento de los primeros cristianos heréticos y heterodoxos? (Madrid: EDAF, 2007)-. En realidad, este rasgo, el de la aparición de grupos minoritarios ortodoxos-heterodoxos -los heterodoxos son siempre los otros-, es algo común en todos los movimientos ideológico-religiosos, como también suele serlo la consideración negativo-destructiva, sectaria, de aquellas creencias, en especial las religiosas, con las que se compite o que no se comparten.

47 Francisco Díez de Velasco, «La enseñanza de las religiones en la escuela en España: análisis del modelo de aula segregada», Historia y Memoria de la Educación 4 (2006): 277-306.
} 
La libertad de pensamiento, conciencia y religión de los menores exige en el fondo, aun teniendo cuenta su adecuación al contexto familiar, la aplicación de criterios similares en relación con los padres. La posición de Nussbaum en este punto es clara: se pronuncia -comentando la demanda judicial de unos padres opuestos al uso de determinados libros escolares- contra aquellos padres renuentes a exponer a sus hijos «a otras formas de religión y a los sentimientos, actitudes y valores de otros estudiantes que contradigan» sus «concepciones religiosas» salvo que se les aclare que «los otros puntos de vista son incorrectos» y los suyos "correctos».48 "¿Por qué es importante para la tolerancia cívica la exposición a concepciones divergentes?», se pregunta Nussbaum. La razón es obvia:

a niños a quienes en casa se enseña a pensar que solo su propio punto de vista es bueno y que todos los demás son inicuos (no solo errados) [...] les resultará difícil alcanzar la actitud del igual respeto. Hasta el reconocimiento de una humanidad básica en otro supone un logro, no algo que podamos dar por sentado. El hecho de ver como igual a otro que podría ser fácilmente tratado como inferior, no plenamente humano, requiere llegar a conocer al otro un poco, escuchar su historia. La comprensión no asegura el reconocimiento, pero la ignorancia prácticamente es garantía de no reconocimiento en un clima de polarización y desconfianza. ${ }^{49}$

\section{EL TRATAMIENTO JUDICIAL DE LOS DERECHOS DE LOS PADRES Y DE LOS MENORES EN CASO DE DIVERGENCIA O CONFLICTO}

No creo que haya dudas sobre la constitucionalización, en España, de la Convención sobre los Derechos del Niño de 1989 desde su ratificación el 30 de noviembre de 1990. Hemos expuesto, además, lo fundamental de su desarrollo legislativo en relación, sobre todo, con los derechos-libertades de los menores. Queda por ver el tratamiento y aplicación, o no aplicación, judicial de la misma en los casos de conflicto entre los padres -por su pertenencia a distintas confesiones religiosas-, o entre

\footnotetext{
48 Nussbaum, La libertad de conciencia, 334.

49 Nussbaum, La libertad de conciencia, 337.
} 
estos y los poderes públicos por oponerse a aquellas enseñanzas que, a su juicio, no están acordes con sus convicciones religiosas y morales. Por el uso que en los tribunales españoles se ha hecho, y hace, de las resoluciones del Tribunal Europeo de Derechos Humanos (TEDH) en este tema, aludiremos también a algunos de los casos planteados ante el mismo. ${ }^{50}$

\section{Sentencias relativas a casos de discrepancia entre los cónyuges sobre la educación religiosa de los hijos}

Se trata de sentencias judiciales dictadas, por lo general, tras o con ocasión del divorcio de los cónyuges. Los casos analizados son siete de otras tantas Audiencias provinciales, uno del TS y tres del TEHD. Sus fechas oscilan entre 1980 y 2008 -dos son anteriores a la ratificación del Convenio de 1989- en el primero y segundo caso. Las sentencias del TEDH son una de 1993 y dos de 2013.51

Dos son los criterios que prevalecen en las resoluciones judiciales: el de la continuidad en la formación religiosa del menor y, al menos de modo teórico, el de tener en cuenta su interés superior. Dicho esto, se observan diferencias en la valoración de dichos criterios, la no vigencia del derecho del menor a ser escuchado en aquellos casos en que por su edad debería habérsele oído, y el predominio de interpretaciones favorables a la religión mayoritaria del país, frente a las minoritarias, a la hora de conceder o denegar la guarda y custodia de los hijos a uno u otro cónyuge, o incluso de quitar la patria potestad a alguno de ellos. Sin entrar en detalles, dos son las cuestiones que destacaría: la del concepto de "proselitismo abusivo", y la del tipo de formación religiosa adecuada para los hijos que salvaguarde el derecho de los padres a educarlos de

\footnotetext{
50 No se han consultado directamente todas las sentencias judiciales a las que se alude, solo las más relevantes. En tales casos, su análisis se efectúa a partir de la exposición de las mismas efectuada, con mayor o menor detalle, por quienes, desde el mundo del derecho, las han estudiado y comentado. Por supuesto, se indicarán las fuentes secundarias utilizadas. La naturaleza y propósitos de este ensayo, junto con los de la revista y sus lectores habituales, así como la extensión del mismo, justifican el tipo de análisis llevado a cabo.

51 La información aquí sintetizada se toma, entre otros trabajos que oportunamente se mencionan, de Cebriá García, «El derecho a la libertad religiosa del menor», 149-154; Liñán García, «La protección jurídica del menor»; Souto Galván, «La libertad de creencias del menor»: 209-214; y, para las sentencias del TEDH, Meix Cereceda, El derecho a la educación, 70-103.
} 
acuerdo con sus convicciones en el supuesto no inhabitual, sobrevenido o no, de que difieran.

El concepto de "proselitismo abusivo» es introducido, por ejemplo, por Cebriá García al comentar una sentencia de la Audiencia Provincial de Salamanca de 1999, en la que se desestimó la petición paterna de privar a la madre de la guarda y custodia de la hija menor por pertenecer a los Testigos de Jehová. Ante "un eventual "proselitismo abusivo"», dice, el tribunal falla que "la madre no podrá llevar a su hija a ningún acto religioso sin el consentimiento del padre».52 Por su parte, Liñán García menciona dicho concepto al referirse a aquellos casos, cada vez más comunes, en los que surgen conflictos entre el ejercicio de la libertad religiosa por el menor, cuando se estima que tiene suficiente madurez para ello, y las creencias de los cónyuges o de alguno de ellos. Y, aunque los cónyuges tendrían, dice, «que tender a ser imparciales ante el fenómeno religioso, la realidad nos muestra que -en muchos casosintentarán convencer al menor para que siga las convicciones religiosas e ideológicas por ellos profesadas», pudiendo incurrir en "proselitismo abusivo». ${ }^{53}$ Una noción o concepto que entiende que es solo aplicable cuando, por su madurez -apreciable en España judicialmente-, el menor puede ejercer el derecho de libertad religiosa, no en edades o momentos anteriores. En su opinión, «debemos partir de la idea de que cuando el menor, debido a su escasa edad, no sea capaz de adoptar decisiones por sí mismo, la religión o convicción en la que será educado lógicamente, será la que le inculquen sus padres en función del derecho reconocido en los textos internacionales de Derechos Humanos y a nivel constitucional (art. 27.3)» de que sus hijos reciban una educación religiosa y moral acorde con sus convicciones. ${ }^{54}$ No se plantea la posibilidad, por lo demás obvia y bastante generalizada, de que también en dichas edades pueda producirse un "proselitismo abusivo», sea por los padres o por otras personas con su consentimiento. Basta que se lleve a cabo considerando de forma expresa o implícita, como se decía en la cita anterior de Nussbaum, que las demás creencias son no ya erradas sino inicuas, que no se les enseñe a respetarlas, o incluso, añadiría, que

\footnotetext{
52 Cebriá García, «El derecho a la libertad religiosa del menor», 150.

53 Liñán García, «La protección jurídica del menor», 22.

54 Liñán García, «La protección jurídica del menor», 17-18.
} 
se le oculte, como decía Blanco White, que las convicciones o creencias que se le transmiten o en las que es socializado, admiten diversas interpretaciones y formas de vivirlas, o que no se respete el hecho de que el menor, a su modo y manera -como cualquier adulta-, está dando forma a las suyas propias.

¿Cuál es, según la jurisprudencia, el tipo de formación religiosa adecuada para los hijos que salvaguarda el derecho de los padres a educarlos de acuerdo con sus convicciones en el supuesto no inhabitual -sobrevenido o no tras el matrimonio o relación- de que difieran?

Como se dijo, el criterio de la continuidad en la formación religiosa de los hijos y el del interés superior del menor -un concepto susceptible de interpretaciones divergentes, y subjetivas, en su aplicación-son, por lo general, los que prevalecen en los tribunales. Pero no siempre del mismo modo en cuanto a su alcance. Las sentencias no siguen, en este punto, un criterio unánime y en más de un caso han tenido que ser rectificadas en instancias superiores tras el recurso correspondiente. Hay tribunales que desestiman las peticiones para privar al otro cónyuge de la patria potestad o de la guarda y custodia de los hijos por motivaciones religiosas. Otros, sin embargo, establecen restricciones en el régimen de visitas y comunicación entre el menor y aquel cónyuge que, por lo general, profesa creencias no mayoritarias en el país del que se trate. En este supuesto, la sentencia del TEDH de 12 de febrero de 2013 -caso Vojnity contra Hungría- entendió que la medida de suprimir el régimen de visitas al padre de un menor por considerar que sus creencias religiosas, y su insistencia proselitista, podrían ser dañinas para este, era desproporcionada y solo podía acordarse en el supuesto de que dichas creencias o proselitismo supusieran «prácticas peligrosas o expusieran a su hijo a un daño físico o psicológico». ${ }^{55} \mathrm{El}$ TEDH admitió pues, en este caso, que el proselitismo per se no afecta negativamente a los derechos y libertades del menor salvo cuando supone un perjuicio para su salud física o mental, una cuestión que en unos casos podrá ser obvia -en uno u otro sentido-, pero que en otros se presta a muy diversas y subjetivas interpretaciones, en especial por lo que se refiere a la salud mental.

55 Souto Galván, «La libertad de creencias y el interés superior del menor», 212. 
Una sentencia de la Audiencia Provincial de Castellón de 2006, desestimó el recurso de apelación interpuesto por la madre de un menor contra la resolución de un Juzgado de $1^{\text {a }}$ Instancia que autorizaba «al padre a educar a su hijo en la fe católica» en un proceso de divorcio. La recurrente sostenía que, de no mediar acuerdo entre los progenitores, no podía determinarse judicialmente cuál de las dos opciones religiosas debía primar sobre la otra. La decisión judicial desestimó el recurso argumentando, por un lado, que lo solicitado vulneraba la libertad religiosa del padre. Por otro, que si al alcanzar la mayoría de edad, el menor optaba por unas u otras creencias religiosas, tal y como la madre prefería, «mal podrá hacerlo si durante sus años de formación no recibe ningún conocimiento de enseñanzas religiosas». El tribunal, además, se explayaba en su argumentación haciendo una serie de consideraciones sobre la libertad y la formación religiosa de los menores que iban más allá del caso: desde la «importancia sociológica e histórica del catolicismo en España» y «en el mundo occidental», hasta la necesidad de una formación religiosa, por supuesto católica, como parte «importante» de una «formación integral de los hijos», y la relevancia del «hecho religioso» en «la civilización y la cultura de los pueblos». Todo ello para, tras rechazar la exclusión del adoctrinamiento y la práctica en una confesión religiosa determinada hasta la mayoría de edad, con el fin de que el menor pudiera ejercer entonces la «libertad religiosa con plenitud de madurez y conocimientos» -como solicitaba la madre-, exponer, en un largo párrafo sin desperdicio, cuál debía ser, a su juicio, el tipo de formación religiosa de los hijos que garantiza dicho ejercicio:

No creemos $[\ldots]$ que la única manera posible de acercarse a la religión sea a partir de una previa formación más o menos completa sobre el hecho religioso y las religiones, que pocas personas -aun mayores de edad tienen-. Parece poco realista creer que es posible que la persona tan solo se pueda y se deba iniciar en el hecho religioso y en las prácticas religiosas después de haber estudiado y reflexionado sobre la religión, en base a una formación completa y plural -sobre las diversas opciones religiosas y creencias- que pocas personas tienen y a la que es claro que es difícil acceder durante la minoría de edad. Estos planteamientos abocarían prácticamente a no reconocer más posibilidad de ejercicio responsable de la libertad religiosa de los menores de edad que el 
no profesar religión o creencia algunas; limitándose la relación del menor con el hecho religioso a la sola formación -información- aséptica y distanciada sobre las diversas religiones y creencias.

Como ha observado Beatriz Souto, de quien se toman las citas y referencias anteriores, el artículo 18 del Pacto Internacional de Derechos Civiles y Políticos de 1966, que establece la libertad de pensamiento, conciencia y religión, "protege las creencias teístas, no teístas y ateas, así como el derecho a no profesar ninguna religión o creencia». Con independencia de ello, y en relación con el caso planteado -en el que, como es usual, el menor no fue escuchado-, sostiene que

en aquellos supuestos en los que los menores no pueden decidir y no se alcanza un acuerdo por parte de los progenitores, la resolución puede adoptarse teniendo en cuenta la preservación de la identidad religiosa del menor. Sin embargo, en el caso de que todavía no se haya formado esta, la solución más adecuada [...] es la formación en los valores de ambos progenitores, excluyendo [...] la adscripción efectiva de los menores a una confesión religiosa hasta que alcancen suficiente madurez para tomar esa decisión por sí mismos, puesto que impediría la posibilidad de una formación plural que respete el derecho de ambos progenitores a educar a sus hijos de conformidad con sus propias convicciones, es decir, a guiarlos en el ejercicio de su libertad religiosa hasta que puedan ejercitarla plenamente. ${ }^{56}$

Una propuesta de solución realista y acomodada a lo que en estos momentos podría ser el mínimo posible, dada la mentalidad e ideología de buena parte de la doctrina y sobre todo de la judicatura, que además podría tener respaldo en la Sentencia del TC 141/2000, de 28 de mayo, dictada en un recurso de amparo interpuesto por el padre de dos menores de 5 y 12 años, miembro del Movimiento Gnóstico Universal que, por su pertenencia a esta confesión religiosa, había visto restringido por la Audiencia Provincial de Valencia, a instancias de la madre, el régimen de visitas en un proceso de divorcio. Es decir, en una serie de consideraciones

\footnotetext{
56 Souto Galván, «La libertad de creencias y el interés superior del menor», 216-217.
} 
efectuadas en relación con este caso que, por su índole general, van más allá del mismo:

Desde la perspectiva del art. 16 C.E. [que garantiza la libertad ideológica, religiosa y de culto] los menores de edad son titulares plenos de sus derechos fundamentales, en este caso, de los derechos a la libertad de creencias y a su integridad moral, sin que el ejercicio de los mismos y la facultad de disponer sobre ellos se abandonen por entero a lo que al respecto puedan decidir aquellos que tengan atribuida su guarda y custodia o, como en este caso, su patria potestad, cuya incidencia sobre el disfrute del menor de sus derechos fundamentales se modulará en función de la madurez del niño y los distintos estadios en que la legislación gradúa su capacidad de obrar [...].

En resumen, frente a la libertad de creencias de sus progenitores y su derecho a hacer proselitismo de las mismas con sus hijos, se alza como límite, además de la intangibilidad de la integridad moral de estos últimos, aquella misma libertad de creencias que asiste a los menores de edad, manifestada en su derecho a no compartir las convicciones de sus padres o a no sufrir sus actos de proselitismo, o más sencillamente, a mantener creencias diversas a las de sus padres, máxime cuando estas pudieran afectar negativamente a su desarrollo personal. Libertades y derechos de unos y de otros que, de surgir el conflicto, deberán ser ponderados teniendo siempre presente el «interés superior» de los menores de edad. ${ }^{57}$

\section{Sentencias relativas a la objeción de conciencia o veto parental a la acción, en materia educativa, de los poderes públicos}

La inclusión en la Ley Orgánica de Educación (LOE) de 3 de mayo de 2006 de la asignatura de Educación para la Ciudadanía (EpC), bajo esta u otra denominación, en las enseñanzas primaria y secundaria, dio lugar a una amplia polémica social y jurídico-doctrinal sobre la posibilidad o no de que los padres ejercieran, en relación con ella, la objeción de conciencia -se ha hablado de unos 52.000 objetores-, así como a una

57 Sentencia del TC 141/2000, de 29 de mayo, BOE de 30 de junio de 2000: 44-45. 
serie de litigios judiciales -sobre los 3.000- hasta llegar, tras divergentes sentencias de varios Tribunales Superiores de distintas Comunidades Autónomas, a las cuatro sentencias del TS de 11 de febrero de 2009 que declaraban la constitucionalidad de la nueva disciplina y la imposibilidad de ejercer la objeción de conciencia frente a ella. ${ }^{58}$ Buena prueba de la divergencia de opiniones e interpretaciones judiciales es tanto el hecho de que las de los tribunales superiores autonómicos fueran contradictorias entre sí, como la existencia en la mayoría de ellas de votos particulares que bien podríamos calificar de contra-sentencias.

En la primera sentencia, dictada por el Tribunal Superior de Cataluña en 2007, no se dio trámite al recurso de los padres por entender que no existía precepto alguno que estableciera un derecho a la objeción de conciencia que permitiera no cursar dicha materia. En el año 2008 el Tribunal Superior de Asturias desestimó otro recurso por entender que los padres no habían logrado probar el carácter moralmente invasivo, y contrario al derecho reconocido en el art. 27.3 CE, del contenido de la nueva asignatura. Otra cosa, se decía, podría haber sido si el objeto del recurso hubiera recaído no sobre la disposición legal (la LOE) que la establecía, sino sobre algún acto concreto en relación con la enseñanza de la materia. Ese mismo año, 2008, los Tribunales Superiores de Andalucía y La Rioja admitían, sin embargo, la posibilidad de que los padres ejercieran la objeción de conciencia por entender que la nueva materia tenía un carácter inequívocamente moral como se desprendía del contenido de los Reales Decretos que establecían sus enseñanzas mínimas y de los Decretos y Órdenes que los desarrollaban a nivel autonómico.

En sus cuatro sentencias de 11 de febrero de 2009 el TS entendió, primero, que no existía, en este caso, un derecho constitucional a la objeción de conciencia derivado del derecho a la libertad religiosa (art. 16 CE) o de cualquier otro precepto constitucional o legal donde expresamente se

\footnotetext{
58 Tanto la nueva disciplina como la sentencia mencionada originarían un debate doctrinal del que, a título de ejemplo, se indican algunos de los trabajos utilizados en esta síntesis: Göran Rollnert Liern, «La neutralidad ideológica del Estado y la objeción de conciencia a la "Educación para la Ciudadanía”", Cuadernos Constitucionales de la Cátedra Fadrique Furió Ceriol 60-61 (2007): 271-302; Germán Gómez Orfanel, «Jurisprudencia española sobre educación para la ciudadanía», Anuario de Derechos Humanos 10 (2009): 261-283; Lourdes Ruano Espina, «Las sentencias del Tribunal Supremo de 11 de febrero de 2009 sobre la objeción de conciencia a EPC», Revista Española de Derecho Canónico 66 (2009): 211-274; y Beatriz Souto Galván, Educación y creencias, 111-127, entre otros.
} 
reconociera. Y, segundo, que la nueva materia era en sí misma constitucional, dejando abierta la posibilidad, por lo demás obvia en esta asignatura o en cualquier otra, de que los padres recurrieran cualquier tipo de actuación del centro docente o del profesorado que estimaren que conculcaba el derecho reconocido en el art. 27.3, incluso solicitando su suspensión cautelar.

Dado que tanto en las controversias doctrinales como en las sentencias de los tribunales autonómicos o del TS se comentan, interpretan y utilizan como fundamento criterios mantenidos en diversas sentencias del TEDH -Kjelsen y otros contra Dinamarca (1976), Jiménez Alonso y Jiménez Merino contra España (2000), Folgerø y otros contra Noruega (2007) y Zengin contra Turquía (2007)- dictadas con motivo de los recursos interpuestos por los padres por entender que sus Estados no respetaban el derecho a educar a sus hijos de acuerdo con sus convicciones religiosas y filosóficas -art. 2 del Protocolo 1 del Convenio Europeo de Derechos Humanos-, parece conveniente efectuar una síntesis de dichos criterios. $^{59}$

En dos de dichos casos (Folgerø y Zelgin) los Estados respectivos habían introducido en el currículum escolar obligatorio las asignaturas de «Cristianismo, Religión y Filosofía» (Noruega) y «Cultura religiosa y ética» (Turquía), y los padres consideraban que sus contenidos vulneraban el mencionado derecho. El TEDH estimó ambos recursos. En el caso noruego, pese a la naturaleza no confesional de la materia y a la posibilidad abierta de que ser eximido de la asistencia cuando los contenidos pugnasen con las convicciones religiosas de los padres, el TEDH considero, por un lado, que el currículo no podía ser impartido de modo objetivo, crítico y pluralista dado el predominio cuantitativo y cualitativo en el mismo de la religión cristiana y que el alumnado tenía que llevar a cabo actividades de naturaleza religiosa. Y, por otro, que la mencionada exención parcial, razonada, conculcaba el derecho a la libertad religiosa de los recurrentes. En el caso turco, en que los progenitores profesaban el alevismo -una rama del Islam- el TEDH estimó, asimismo, que el currículo de la materia seguía en general y daba más relevancia a las

\footnotetext{
59 Análisis más detallados pueden verse en Benito Aláez Corral, «Caso Folgero y respeto a las convicciones morales de los padres en materia educativa», Repertorio Aranzadi del Tribunal Constitucional (Pamplona: Aranzadi, 2008), 13-29; Souto Galván, Educación y creencias, 31-39; y Meix Cereceda, El derecho a la educación, 76-103.
} 
creencias del Islam suní, mayoritario en Turquía. En ambos casos, el TEDH tuvo en cuenta «ante todo la posición predominante de los contenidos y valores de una religión sobre las restantes concepciones de la vida y del mundo y, en el caso de Folgerø, también la práctica de un culto encubierto». ${ }^{60}$

En los otros dos casos (Kjeldsen y Jiménez Alonso) el recurso de los padres versaba sobre otra cuestión no menos polémica: la educación sexual. Ambos fueron desestimados. En el primero de ellos, tres familias demandaban al Estado danés porque no se contemplaba la posibilidad de eximir a sus hijos de la educación sexual establecida, con carácter obligatorio, en las escuelas públicas. La sentencia, dictada en 1976, estableció los criterios para determinar si la enseñanza de una disciplina puede ser calificada, o no, de contraria a las convicciones de los padres: objetividad, sentido crítico-científico y pluralismo. Examinó las enseñanzas recurridas, consideró que satisfacían dichos criterios, que no suponían un adoctrinamiento dirigido a defender un comportamiento sexual determinado, y desestimó las pretensiones de los padres.

En la segunda sentencia, el padre de una alumna de 13 años que cursaba 8. $^{\circ}$ de Educación General Básica en Treceño (Cantabria) se había negado, por estimarlo contrario a sus convicciones morales y religiosas, a que su hija siguiera las enseñanzas y fuera examinada del contenido de un folleto sobre sexualidad humana editado por la Consejería de Educación de Canarias y proporcionado por el profesor de Ciencias Naturales dentro del tema relativo a las «Funciones vitales». El TEDH desestimó el recurso por entender que el folleto en cuestión ofrecía al alumnado no solo una información objetiva y científica sobre temas tales como las enfermedades de transmisión sexual, el sida, los embarazos no deseados, los métodos anticonceptivos, etc., todos ellos de información general, sino que no abogaba por un comportamiento sexual determinado.

Aunque ambas sentencias circunscribían su decisión al ámbito de la red escolar pública y, en el caso español, el TEDH estimaba que el padre podía haber matriculado a su hija en un colegio privado acorde con sus convicciones religiosas y morales, Meix Cereceda considera que «la idea de la salud pública» constituye la "verdadera clave» de ambos

60 Meix Cereceda, El derecho a la educación, 100. 
pronunciamientos judiciales, lo que justificaría, a su juicio, la introducción de «la educación sexual también en los centros de titularidad privada»; es decir, en el currículum obligatorio. ${ }^{61}$

\section{CONSTITUCIÓN Y EDUCACIÓN: NEUTRALIDAD Y PLURALISMO62}

En la Exposición de Motivos de la LOPJM de 1996 -ihace veintiséis años!- se decía que «las transformaciones sociales y culturales operadas en nuestra sociedad» habían originado cambios «en el status social del niño» y «un nuevo enfoque» en "la construcción del edificio de los derechos humanos de la infancia» basado en «el reconocimiento pleno de la titularidad de los derechos en los menores de edad y de una capacidad progresiva para ejercerlos». Seis años antes -ihace treinta y dos años!- el Estado español había incorporado a su ordenamiento jurídico en su más alto nivel, al ratificarla, la Convención de 1989. En el ámbito educativo constitucional dicha ratificación cuestionaba u obligaba, como mínimo, a replantearse la interpretación dominante que se venía haciendo de los derechos y libertades educativas fundamentales, no solo en el campo doctrinal sino sobre todo en el judicial. Una interpretación, como se dijo, asentada en dos arcos de bóveda -el art. 27.3 CE que garantiza el

\footnotetext{
${ }_{61}$ Meix Cereceda, El derecho a la educación, 94. Una interpretación en parte divergente de ambas sentencias, dentro de la orientación católico-conservadora, puede verse en Pablo Nuevo López, «Educación sexual y derechos fundamentales. Contribución a un debate necesario», Revista de Derecho Político (UNED) 80 (2011): 131-137.
}

62 Puede extrañar, como observaba uno de los evaluadores de este texto, que no se haga mención o analicen en él los tres informes de 1993, 1998 y 2009 presentados por el gobierno español al Comité de los Derechos del Niño de las Naciones Unidas sobre el cumplimiento por España de la Convención de 1989 (https://tbinternet.ohchr.org/_layouts/15/treatybodyexternal/Download.aspx?symbolno $=\mathrm{CRC} \% 2 \mathrm{fC} \% 2 \mathrm{fESP} \% 2 \mathrm{f} 3-4 \&$ Lang=en), así como el «examen» $\mathrm{y}$ «observaciones» sobre dichos informes elaborado por el mencionado Comité en 2010 (https:/tbinternet.ohchr.org/_layouts/15/ treatybodyexternal/Download.aspx?symbolno=CRC\%2fC\%2fESP\%2f3-4\&Lang=en). Solo haré al respecto dos consideraciones. La primera es que la parte reservada en dichos documentos a los «derechos y libertades civiles» es sensiblemente inferior a la dedicada a otros aspectos y derechos. Ítem más, dentro de ella uno de los temas al que menos atención se presta es el del derecho a la libertad de pensamiento, conciencia y religión. La segunda consideración es que lo que allí se dice en relación con dicha libertad refuerza la tesis aquí mantenida sobre su inoperancia e inanidad práctica, legal y judicial. Los informes se limitan a indicar: a) que dicha libertad está reconocida en la Constitución, en la LOPM de 1996 y en las leyes orgánicas de educación; y b) que la libertad religiosa del menor se satisface a través del art. 27.3 de la $\mathrm{CE}$-es decir, del derecho de los padres a que sus hijos reciban la formación religiosa y moral que esté acorde con sus convicciones-, de la legislación sobre la enseñanza de la religión confesional y con la posibilidad de optar entre dicha enseñanza y otra materia optativa. Por supuesto, toda consideración problemática sobre la aplicación y vigencia de este derecho-libertad brilla por su ausencia. Ya está regulado y satisfecho. 
derecho de los padres a que sus hijos reciban una formación religiosa y moral acorde con sus convicciones, y el 27.6 que reconoce la libertad de creación de centros docentes- de los que se derivaban, como exigencias ineludibles, el derecho de los centros privados, concertados o no, a establecer un ideario, la libertad de elección de centro docente por las familias y, en más de un caso, el derecho a recibir fondos públicos, vía concierto, por todo aquel centro privado que lo solicitase o. incluso, la también necesaria implantación del cheque o bono escolar.

La Convención de 1989 ponía en cuestión ambos derechos y libertades y obligaba, como acaba de decirse, a replantearse esa interpretación dominante y, al menos, a esforzarse por argumentar en favor de su continuidad o vigencia si se estimaba ajustada a derecho. En efecto, por un lado, el art. 29 de dicha Convención limitaba la libertad de creación de centros -y, por tanto, el ideario y la práctica educativa- al exigir la condición, en el ejercicio de dicha libertad, de que se respetaran una serie de principios -incorporados como tales al ideario educativo constitucional junto al art. 27.2 CE- entre los cuales figuraba el, muy concreto, de "preparar al niño para asumir una vida responsable en una sociedad libre, con espíritu de comprensión, paz, tolerancia, igualdad de sexos y amistad entre todos los pueblos, grupos étnicos, nacionales y religiosos, y personas de origen indígena». Por otro, la Convención:

a) Reconocía a los menores la titularidad de la libertad de pensamiento, conciencia y religión, en su art. 14.1, y el derecho a una (in)formación plural en sus arts. 13.1 y 17, así como el de ser escuchado, en función de edad y madurez, en los asuntos que le afectaren (art.12).

b) Utilizaba los verbos guiar y orientar al definir la tarea de los padres en relación con la preparación de los menores para el ejercicio de los derechos que les reconocía (arts. 14.2 y 5 ).

c) Establecía el interés superior del menor como principio o criterio a tener en cuenta sobre cualquier otro.

La Convención de 1989 no solo cuestiona la interpretación dominante de la Constitución en lo que a la educación se refiere, sino también la existencia de una enseñanza confesional religiosa, sobre todo si se financia con fondos públicos o se lleva a cabo en locales o espacios públicos, 
como ya ha advertido algún tratadista. ${ }^{63}$ Asimismo, implica un límite a eso que Blanco White llamaba, como se dijo, el «derecho y deber de todos los padres de apoderarse de la mente de sus hijos, en la más temprana edad, y conformarlas enteramente tomando la suya como modelo", ${ }^{64}$ ya sea que dicho derecho-deber se haga derivar de la libertad religiosa de los padres o del ejercicio de la patria potestad. Una patria potestad, por cierto, que tras la reforma del Código Civil (CC) por ley de 13 de mayo de 1981 "pasa de ser considerada un derecho de los padres, fundamentalmente sobre la persona y bienes de los hijos, a una función: derechos concedidos a los padres para facilitarles el cumplimiento de los deberes inherentes» a la misma. ${ }^{65}$ Es decir, como un deber jurídico impuesto a los padres, que incluye el de «educarlos y procurarles una formación integral»-adjetivo susceptible de muy diversas interpretaciones-, que ha de ejercerse «en beneficio del hijo de acuerdo con su personalidad» (art. 154 CC). Por último, la Convención de 1989 supone también un límite a la libertad de cátedra del profesorado de cualquier nivel educativo o modalidad de enseñanza tanto en los centros públicos como privados. Obliga, por tanto, a replantearse la naturaleza del principio de neutralidad establecido por la Sentencia del TC 5/1981 de 13 de febrero, solo para los centros públicos, como «obligación de renuncia a cualquier tipo de adoctrinamiento ideológico», ${ }^{66}$ y, como es obvio, su extensión o no a todo tipo de profesorado, público o privado.

El principio de neutralidad deviene exigencia y efecto del principio de pluralismo que conforma, junto con otros, el ideario educativo constitucional. Dicho principio puede ser entendido, desde una perspectiva pasiva, como pura asepsia o impedimento para tratar temas controvertidos que puedan suscitar el veto parental -posición con predicamento en una buena parte de la doctrina y, desde luego, en la judicatura- o, desde una perspectiva activo-positiva, como el tratamiento de cualquier tema o cuestión -entre ellos, las diversas creencias- de forma objetiva, crítico-científica y plural. Con independencia de ello, el mandato del TC

\footnotetext{
63 Sergio A. Fernández Parra, El principio de neutralidad religiosa y la asignatura de religión en España (Bogotá: Departamento de Derecho Constitucional. Universidad Externado de Colombia, 2017).

64 Blanco White, Sobre educación, 305.

65 Asensio Sánchez, «Libertad religiosa del menor», 21.

66 Sentencia del TC 5/1981, de 13 de febrero, suplemento al BOE de 24 de febrero de 1981, 20.
} 
de limitar su vigencia, de modo exclusivo, al sector público, además de ser un contrasentido en sí mismo -debería aplicarse también, según su propia lógica argumentativa, a aquellos centros docentes que reciben fondos públicos y no poseen un ideario religioso-moral- se basa en la opción interpretativa que entiende que dicho pluralismo se satisface a través de la libertad de creación de centros docentes privados y, caso de solicitarlo, de su concertación. Es decir, mediante el pluralismo intercentros.

Dejo a un lado la imposible existencia real de dicho pluralismo dada la heterogeneidad ideológica de la sociedad española. Una realidad que impedirá en bastantes casos que los padres hallen un centro docente, cercano o no, acorde con sus convicciones religiosas o morales, en especial cuando, como sucede en algunas grandes ciudades, los porcentajes de las enseñanzas pública y privada, concertada o no, son similares. Simplemente mantengo que, una vez ratificada la Convención de 1989, el derecho de los menores a una (in)formación plural y a la libertad de pensamiento, conciencia y religión no pueden satisfacerse ni mediante el pluralismo intercentros ni, como se ha propugnado desde otras posiciones ideológicas, el pluralismo intracentros si por este se entiende la exposición del menor a un contexto educativo en el que cada profesor exprese sin más, de modo exclusivo y excluyente, sus puntos de vista, creencias u opiniones. ${ }^{67}$ Entre otras razones, porque ello no garantiza el tipo de pluralismo educativo que subyace en la Convención de 1989. De ahí que, este punto, el TC no haya ido más allá ni desarrollado lo que argumentaba, de modo general, en la sentencia desestimatoria del recurso de amparo presentado por un grupo de padres y madres que optaba por la "enseñanza en el hogar". Como en dicha sentencia se decía,

el sistema educativo en general y la enseñanza básica en particular [...] han de servir también a la garantía del libre desarrollo de la personalidad individual en el marco de una sociedad democrática y a la formación de ciudadanos respetuosos con los principios democráticos de convivencia y con los derechos y libertades

\footnotetext{
67 Dicho sea de paso, esa es la realidad actual: no solo el profesorado no proporciona en muchos casos una (in)formación plural, objetiva y científica, sino que desde las aulas de religión confesional, historia, literatura o ciencias naturales, entre otras disciplinas, se mantienen, como verdades incontrovertibles, ideas, creencias y opiniones que se contradicen entre sí y que, desde luego, son controvertibles.
} 
fundamentales, una finalidad ésta que se ve satisfecha más eficazmente mediante un modelo de enseñanza básica en el que el contacto con una sociedad plural y con los diversos y heterogéneos elementos que la integran, lejos de tener lugar de manera puramente ocasional y fragmentaria, forma parte de la experiencia cotidiana que facilita la escolarización. ${ }^{68}$

Es difícil encontrar un párrafo más contundente para declarar inconstitucional el modelo de pluralismo intercentros que el TC ha constitucionalizado en diversas sentencias. Si el menor ha de estar en «contacto», en una sociedad plural, con los «diversos y heterogéneos elementos que la integran», y no de modo «ocasional y fragmentario», carece de sentido optar por un modelo de pluralismo, el intercentros, en que los menores son separados en función de la clase social, ideología, religión o creencias de los padres. En un modelo que, como expresaba Giner de los Ríos en 1886, «divide al pueblo casi desde la cuna en castas enemigas» educadas en «instituciones rivales». ${ }^{69}$

La concepción del mundo y de la vida, y en particular de la infancia y de la minoridad -en definitiva, de la sociedad-que subyace e impregna la Convención de 1989 se opone frontalmente a la interpretación hasta ahora dominante en la doctrina y en la judicatura de los derechos y libertades educativas reconocidos en la Constitución. Dicha concepción no carece, como se ha visto, de tradición histórica, pero ha sido en el siglo XX cuando se ha configurado y plasmado legalmente. Se basa, sobre todo, en el respeto a la libre conciencia de los menores y en el deber de los padres -y de los poderes públicos- de promover una formación o tipo de educación que les prepare para el ejercicio autónomo y progresivo de los derechos, libertades y deberes -entre ellos el del respeto hacia las creencias de los demás- propios de una sociedad plural y democrática.

En definitiva, la Convención de 1989 promueve un pluralismo educativo que no es intercentros ni intracentros, sino (in)formativo y a desplegar en cualquier tipo de contexto escolar o no escolar, formal o informal, incluidos el familiar y el religioso. En este sentido, podría afirmarse que

\footnotetext{
68 Sentencia del TC 133/2010, de 2 de diciembre, BOE 5 de enero de 2011: 122.

69 Francisco Giner de los Ríos, «La verdadera descentralización en la enseñanza del Estado», Obras completas (Madrid: La Lectura, 1933), t. XII, 135 y 137.
} 
dicha Convención se sitúa dentro de un «liberalismo pluralista» en el que la intervención estatal se dirige a «asegurar que los niños tienen los suficientes recursos intelectuales para participar en los procesos que se desarrollan en el marco de una sociedad plural y democrática», y "proteger el derecho del menor a un futuro abierto, en el que la elección entre las distintas concepciones del bien se produzca autónomamente». ${ }^{70}$ Un pluralismo que convierte en abusivo -por la dependencia e indefensión del menor- cualquier tipo de proselitismo o adoctrinamiento exclusivo, excluyente, etnocéntrico o supremacista. ${ }^{71}$ Que entiende la patria potestad como una facultad que se ejerce, entre otras cosas, para hacer posible la formación en el ejercicio de la libertad de pensamiento, conciencia y religión de los hijos. Un ejercicio que, como todos, se aprende ejercitándolo, no inhibiéndolo, abortándolo o encorsetándolo antes de que se conforme. El derecho parental reconocido en el art. 27.3 CE solo tiene sentido, desde esta perspectiva, al servicio no de los padres sino del derecho de los hijos a una educación plural y en libertad, ${ }^{72}$ así como, por supuesto, frente a injerencias externas, sobre todo-aunque no solode los poderes públicos, que se opongan o dificulten dicha educación plural.

La firma y ratificación por el Estado español de la Convención de los Derechos del Niño de 1989 supuso su constitucionalización e incorporación al ordenamiento jurídico. En el campo doctrinal, y por lo que respecta a las libertades y derechos fundamentales, los debates se han centrado en: a) el posible conflicto, sobre todo, entre la libertad ideológica y religiosa de los padres (art. 16.1 CE) y la de los hijos (también art. 16.1 CE) a la que la Convención de 1989 añade, en este caso, la de pensamiento y conciencia (art. 14.1 CDN); b) la conciliación, en algún caso, entre el derecho de los padres a que sus hijos reciban una formación religiosa y moral acorde con sus convicciones (art. 27.3) y la mencionada libertad de pensamiento, conciencia y religión del menor y su

\footnotetext{
70 Borja Barragué Calvo, «Neutralidad liberal y libertad religiosa. Consecuencias de la STC 133/2010 para la práctica del homeschooling», Estudios de Deusto 59, n. ${ }^{\circ} 1$ (2011): 35.

71 Proselitismo: empeño o afán con que una persona o una institución tratan de convencer y ganar seguidores o partidarios para una causa o doctrina. Adoctrinar: transmitir una doctrina a una persona para que la haga propia.

72 Benito Aláez Corral, «Artículo 27. El derecho a una educación democrática, libre y plural», en Comentario a la Constitución española. 40 aniversario 1978-2018, dirs. Pablo Pérez Tremps y Alejandro Sáiz Arnáiz; coord., Carmen Montesinos Padilla (Valencia: Tirant lo Blanch, 2018), t. I, 614.
} 
derecho a una (in)formación plural (arts. 13.1, 14.1 y 17 CDN); y c) la nueva concepción de la patria potestad que dicha Convención indirectamente comporta en concordancia, por lo demás, con la del Código Civil tras la reforma de 1981.

Ante la clara oposición entre la interpretación dominante en el campo de los derechos y libertades educativo-constitucionales y la Convención de 1989, en unos casos, sobre todo al comienzo, se optó por el silencio, bien porque se partía del prejuicio de que era impensable que se cuestionaran tanto el derecho parental del art. 27.3 CE como la libertad de creación de centros docentes, de establecimiento de un ideario de centro y de elección de centro docente, bien porque se entendía que lo dispuesto en dicha Convención no afectaba o guardaba relación alguna con dichos derechos y libertades. En otros casos, cada vez con más intensidad, un sector doctrinal se planteó algo que no podía ser soslayado por más tiempo: había que tratar de conciliar los derechos y libertades del menor, esa nueva concepción de la infancia y minoridad -del mundo y de la vida, de la sociedad- que impregna toda la Convención de 1989, con la concepción, claramente opuesta, de dichas infancia y minoridad - del mundo y de la vida, de la sociedad- no tanto en la Constitución como en la interpretación doctrinal y judicial que se hacía, y hace, de ella. El resultado ha sido una amplia diversidad de criterios, opiniones e interpretaciones -de las que hemos procurado ofrecer una apretada síntesis- intentando, en un esfuerzo a veces encomiable, cuadrar el círculo haciendo compatibles dos concepciones contrapuestas. En el ámbito judicial, sin embargo, ha seguido vigente, con algún matiz excepcional, la interpretación considerada ortodoxa: la «Constitución educativa del pluralismo» es la del pluralismo intercentros, la de la pluralidad de «ofertas educativas» ideológicamente diferenciadas, aquella que hace posible que los padres puedan elegir centro docente y el tipo de educación que desean para sus hijos, así como ejercer el sacrosanto derecho a que sus hijos reciban una formación religiosa y moral acorde con sus convicciones. ${ }^{73}$

El derecho es hermenéutica y aplicación al caso. Y, en este punto, el problema no es la Constitución, un texto «vivo«, sino su interpretación y

\footnotetext{
73 Pablo Nuevo López, La Constitución educativa del pluralismo. Una aproximación desde la teoría de
} los derechos fundamentales (Madrid: UNED, 2009), 74-75. 
quienes la interpretan. Tal y como veíamos en la primera parte de este ensayo, en relación con la educación separada por sexos, el texto constitucional permite interpretaciones muy divergentes en materia de educación. En lo relativo a las libertades y derechos educativos y del menor, las divergencias, su relevancia y alcance, son todavía mayores. Quienes sean designados o elegidos para formar parte del Tribunal Supremo y, sobre todo, del Tribunal constitucional serán, en el futuro, quienes determinen el tipo de pluralismo a aplicar en el sistema educativo español y, con ello, la política educativa. Si continua vigente la interpretación actual, la Convención de 1989 permanecerá inaplicada en el ámbito (in) formativo y educativo. Mejor hubiera sido -más honesto, menos hipócrita- haberla firmado haciendo las mismas reservas que hicieron aquellos países, islámicos o católicos, en los que legalmente o por costumbre, tradición y uso generalizado, los padres y madres tienen el derecho-deber de educar a sus hijos en la religión que profesan, entre otras razones porque sus mentes -así como las de una amplia mayoría de tratadistas y jueces- fueron conformadas en tal tradición o costumbre inveterada.

\section{Nota sobre el autor}

Antonio Viñao Frago es doctor en Derecho y colaborador honorario del Departamento de Teoría e Historia de la Educación de la Universidad de Murcia. Ha sido miembro del Comité Ejecutivo de la International Standing Conference for the History of Education (1996-2000) y presidente de la Sociedad Española de Historia de la Educación (2001-2005), así como director del Centro de Estudios sobre la Memoria Educativa de la Universidad de Murcia (2009-2013) y de la revista Historia y Memoria de la Educación (2014-2019).

Sus campos de investigación prioritarios son la historia de la alfabetización y de la cultura escrita, la escolarización y la enseñanza secundaria, así como la historia del currículum (espacios y tiempos escolares, disciplinas), del profesorado (profesionalización, autobiografías y memorias), de la memoria escolar y el patrimonio histórico-educativo, y de la relación entre las culturas escolares y las reformas y políticas educativas. 


\section{REFERENCIAS}

Aláez Corral, Benito. «Caso Folgero y respeto a las convicciones morales de los padres en materia educativa», Repertorio Aranzadi del Tribunal Constitucional. Pamplona: Aranzadi, 2008, 13-29

Aláez Corral, Benito. «El ideario educativo constitucional como límite a las libertades educativas», Revista Europea de Derechos Fundamentales 17 (2011): 91-129.

Aláez Corral, Benito. «Artículo 27. El derecho a una educación democrática, libre y plural», en Comentario a la Constitución española. 40 aniversario 1978-2018, dirigido por Pablo Pérez Tremps y Alejandro Sáiz Arnáiz; coordinado por Carmen Montesinos Padilla, t, I, 601-619. Valencia: Tirant lo Blanch, 2018.

Álvarez Vélez, María Isabel. «La política de protección de menores en el ámbito internacional». En J. Rodríguez Torrente (ed.). El menor y la familia: conflictos e implicaciones (Madrid: Universidad Pontificia Comillas, 1998), 173188.

Asensio Sánchez, Miguel Ángel, «Libertad religiosa del menor y relaciones paterno-filiales: conflictos». Revista Española de Derecho Canónico 72 (2015): 13-32.

Barragué Calvo, Borja. «Neutralidad liberal y libertad religiosa. Consecuencias de la STC 133/2010 para la práctica del homeschooling», Estudios de Deusto 59, n. ${ }^{\circ} 1$ (2011): 11-39.

Blanco White, José María. Sobre educación. Madrid: Biblioteca Nueva, 2003.

Blanco White, Joseph (1845). The Life of the Rev. Joseph Blanco White, written by Himself, with Portions of his Correspondance. London: John Chapman, 1845.

Cebriá García, María. «El derecho a la libertad religiosa del menor: Problemas que plantea». Anuario de la Facultad de Derecho, Universidad de Extremadura 19-20 (2001-2002): 129-154.

Dávila Balsera, Paulí y Naya Garmendia, Luis María. «La infancia en Europa: una aproximación a partir de la Convención de los Derechos del Niño». Revista Española de Educación Comparada 9 (2003): 83-133

Dávila Balsera, Paulí, y Naya Garmendia, Luis María. «Los derechos de los niños y niñas en los tratados internacionales. Tres momentos históricos». En P. Dávila y L. M. ${ }^{a}$ Naya (coords.), La infancia en la historia: espacios y representaciones, t. I, 889-899. Donostia: Erein, 2005.

Dávila Balsera, Paulí y Naya Garmendía, Luis María, «La evolución de los derechos de la infancia: una visión internacional», Encounters on Education 7 (2006): 71-93. 
Díez de Velasco, Francsico. «La enseñanza de las religiones en la escuela en España: análisis del modelo de aula segregada». Historia y Memoria de la Educación 4 (2006): 277-306.

Fernández-Miranda Campoamor, Alfonso y Sánchez Navarrro, Ángel J. (1996). «Artículo 27: Enseñanza». En Óscar Alzaga Villamil (dir.), Comentarios a la Constitución española de 1978. T. III, 157-152. Madrid: Cortes Generales / Editoriales de Derecho Reunidas, 1996.

Fernández Parra, Sergio A. El principio de neutralidad religiosa y la asignatura de religión en España. Bogotá: Departamento de Derecho Constitucional. Universidad Externado de Colombia, 2017.

García Vilardell, María Rosa. "La libertad de creencias del menor y las potestades educativas paternas: la cuestión del derecho de los padres la formación religiosa y moral de sus hijos». Revista Española de Derecho Canónico 66 (2009): 325-351.

Giner de los Ríos, Francisco. «La enseñanza confesional y la escuela», Obras completas. Madrid: La Lectura, 1922, t. VII, 67-78.

Giner de los Ríos, Francisco, «La política y la escuela, según Kelsen», Obras completas. Madrid: La Lectura, 1927, t. XVI, 251-264

Giner de los Ríos, Francisco. «La verdadera descentralización en la enseñanza del Estado», Obras completas. Madrid: La Lectura, 1933, t. XII, 131-146.

Gómez Orfanel, Germán. «Jurisprudencia española sobre educación para la ciudadanía», Anuario de Derechos Humanos 10 (2009): 261-283.

Grijelmo, Alex. "Los tres problemas del pin parental», El País, 1 de marzo de 2020, suplemento «Ideas», 12.

Key, Ellen. El siglo de los niños (estudios). Barcelona, Heinrich y Ca 1907.

Korczak, Janusz (1993). El derecho del niño al respeto. Cuando vuelva a ser niño. Diario del Ghetto. México D. F.: Trillas, 1993.

Liñan García, Ángeles. "La protección jurídica del menor: especial incidencia de la esfera familiar en su derecho de libertad religiosa y conciencia». Anales de Derecho 32 (2014): 1-30.

Mantecón Sancho, Joaquín. «Nota en torno al contenido y extensión del artículo 27.3 de la Constitución». En Margarita Serna Vallejo y Consuelo Arranz de Andrés (coords.), Estudios de Derecho español y europeo, 541-552, Santander: Publican, 2009.

Ministerio de Educación y Ciencia. Historia de la Educación en España. IV. La educación durante la Segunda República y la Guerra Civil (1931-1939). Madrid: Ministerio de Educación y Ciencia, 1991.

Meix Cereceda, Pablo. El derecho a la educación en el sistema internacional y europeo. Valencia: Tirant lo Blanch, 2014.

Muñoz Arnau, Juan Andrés. Derechos y libertades en la politica y legislación educativas españolas. Pamplona: EUNSA, 2010. 
Nuevo López, Pablo. La Constitución educativa del pluralismo. Una aproximación desde la teoría de los derechos fundamentales. Madrid: UNED, 2009.

Nuevo López, Pablo. «Educación sexual y derechos fundamentales. Contribución a un debate necesario», Revista de Derecho Político (UNED) 80 (2011): 117-148.

Nussbaum, Martha, Libertad de conciencia. En defensa de la tradición estadounidense de libertad religiosa. Barcelona: Tusquets, 2009.

Piñero, Antonio. Los cristianismos derrotados ¿Cuál fue el pensamiento de los primeros cristianos heréticos y heterodoxos? Madrid: EDAF, 2007.

Pombo Sánchez, Antonio. La derrota de la razón. Janus Korczak, médico, educador y mártir. S. 1.: Xoroi Edicions, 2017.

Redondo Andrés, María José. «La libertad religiosa del menor». Anuario de Derecho Eclesiástico del Estado 20 (2004): 131-161.

Rivero Hernández, Francisco, «Límites de la libertad religiosa y las relaciones personales de un padre con sus hijos (Comentario de la STC 141/2000, de 29 de mayo)», Derecho Privado y Constitución 14 (2000): 245-299.

Rodrigo Lara, Belén. «El menor de edad y su derecho de libertad religiosa como agentes determinantes del interés superior del niño», Anuario de Derecho Eclesiástico del Estado XXXV (2019): 351-376.

Rollnert Liern, Göran. «La neutralidad ideológica del Estado y la objeción de conciencia a la "Educación para la Ciudadanía" », Cuadernos Constitucionales de la Cátedra Fadrique Furió Ceriol 60-61 (2007): 271-302.

Ruano Espina, Lourdes. «Las sentencias del Tribunal Supremo de 11 de febrero de 2009 sobre la objeción de conciencia a EPC», Revista Española de Derecho Canónico 66 (2009): 211-274,

Sainz, Fernando (s.a.). Los derechos del niño. Madrid: CIAP, s. a.

Souto Galván, Beatriz. Educación y creencias. Nuevas y viejas cuestiones sobre querellas educativas. Madrid: Dykinson, 2012.

Souto Galván, Beatriz. «La libertad de creencias del menor». Revista Europea de Derechos Fundamentales 28 (2015): 191-220.

Stark, Rodney. La expansión del cristianismo. Un estudio sociológico. Madrid: Trotta, 2009.

UNICEF - Comité País Vasco. «El concepto de niño: de objeto a sujeto de derechos». En P. Dávila y L. M. ${ }^{a}$ Naya. La infancia en la historia: espacios y representaciones. T. I, 900-907. Donostia: Erein, 2005.

Viñao, Antonio. «Educación, jueces y constitución, 1978-2018 (I). La educación separada por sexos». Historia y Memoria de la Educación 11 (2020): 435-473. 